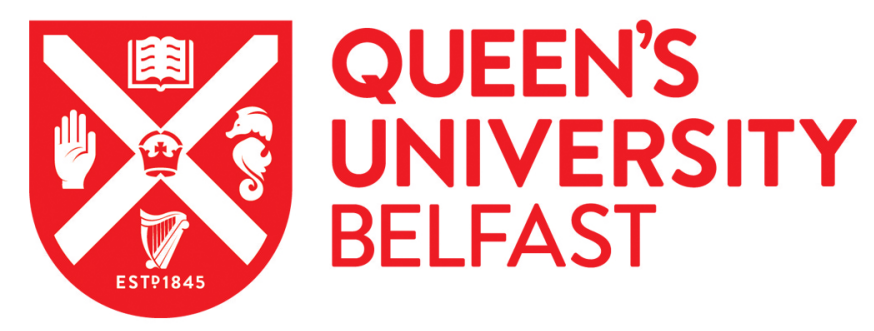

\title{
Whose Voices are Heard? Victimhood and Dark Tourism in Cambodia
}

Lawther, C., Killean, R., \& Dempster, L. (2019). Whose Voices are Heard? Victimhood and Dark Tourism in Cambodia.

Document Version:

Publisher's PDF, also known as Version of record

Queen's University Belfast - Research Portal:

Link to publication record in Queen's University Belfast Research Portal

Publisher rights

(c) 2019 The Authors and QUB.

This work is made available online in accordance with the publisher's policies. Please refer to any applicable terms of use of the publisher.

\section{General rights}

Copyright for the publications made accessible via the Queen's University Belfast Research Portal is retained by the author(s) and / or other copyright owners and it is a condition of accessing these publications that users recognise and abide by the legal requirements associated with these rights.

Take down policy

The Research Portal is Queen's institutional repository that provides access to Queen's research output. Every effort has been made to ensure that content in the Research Portal does not infringe any person's rights, or applicable UK laws. If you discover content in the Research Portal that you believe breaches copyright or violates any law, please contact openaccess@qub.ac.uk. 


\section{WHOSE VOICES ARE HEARD? VICTIMHOOD AND DARK TOURISM IN CAMBODIA}
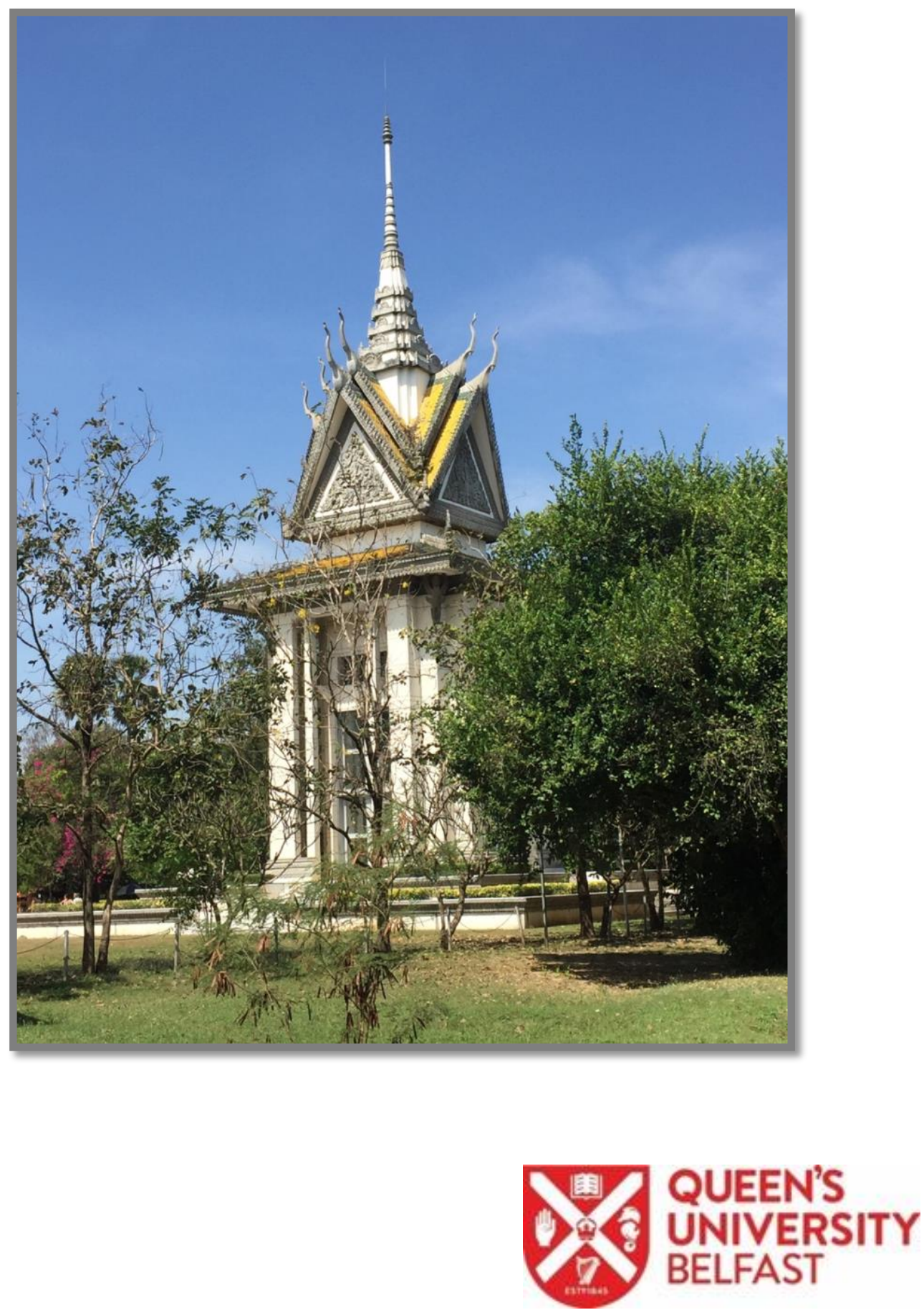
A research report prepared by Dr. Cheryl Lawther, Dr. Rachel Killean and Dr. Lauren Dempster. This research was funded by the Department of Education (Northern Ireland) - Global Challenges Research Fund pilot project scheme.

School of Law

Main Site Tower

Queen's University Belfast

Belfast

County Antrim

Northern Ireland

BT7 1NN

Contact: c.lawther@qub.ac.uk

April 2019

All photos were taken by the research team. 


\section{ACKNOWLEDGEMENTS}

Over the course of this project we are grateful to have received support and assistance from the following. First, this project would not have been possible without the input of Queen's University Belfast and the award of funding from the Department of Education (Northern Ireland) - Global Challenges Research Fund. In Cambodia we were fortunate to be partnered with the Documentation Centre of Cambodia (DC-Cam), a local leader in the work on memory, truth, justice and healing. Farina So and Youk Chhang allowed this partnership to happen. Within DC-Cam, Chenda Seang and Dany Long provided excellent research assistance, translation and logistical support. Most importantly, we owe a considerable debt of gratitude to our interviewees, not only for their time and generosity, but for their willingness to speak to us about the most difficult and sensitive topics. We hope that in some small way, this research report will contribute to supporting their voice and agency as Cambodia continues to transition from the legacy of its past. 


\section{TABLE OF CONTENTS}

EXECUTIVE SUMMARY.

INTRODUCTION: VICTIMHOOD AND DARK TOURISM IN CAMBODIA ............. 10

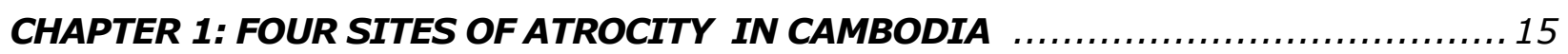

The Tuol Sleng Museum of Genocide and Choeung Ek Killing Fields........................ 15

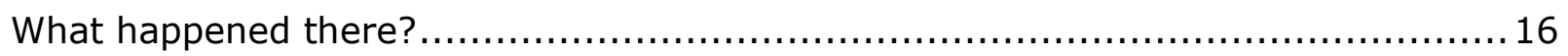

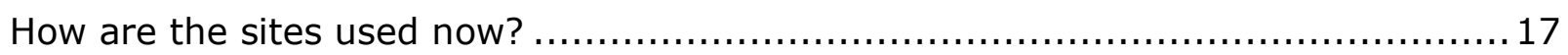

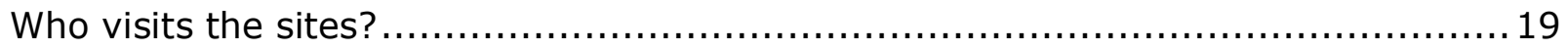

Kraing Ta Chan Peace Learning Centre ................................................ 22

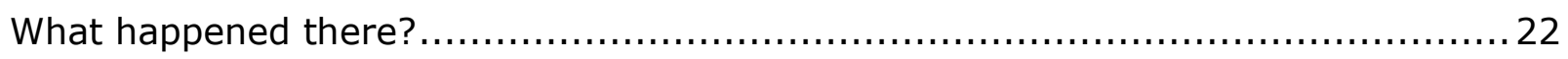

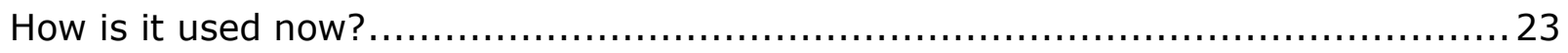

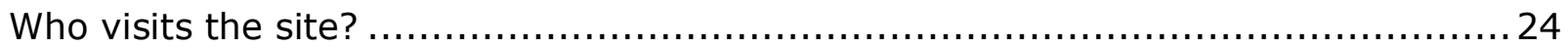

Kampong Chhnang Airfield Construction Site........................................... 25

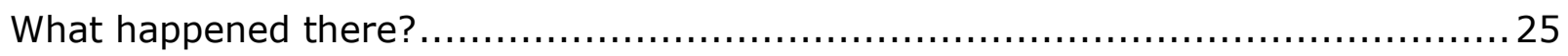

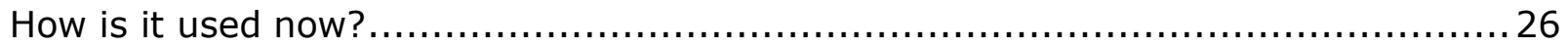

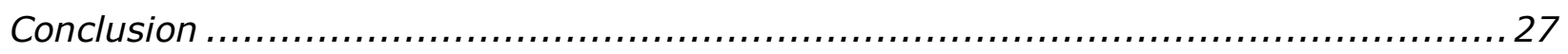

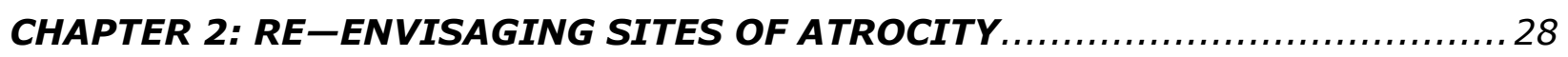

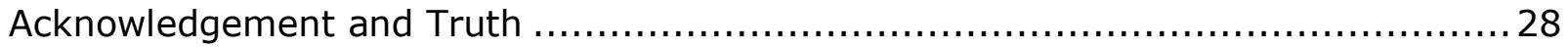

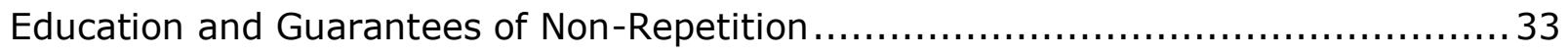

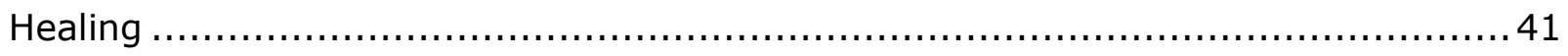

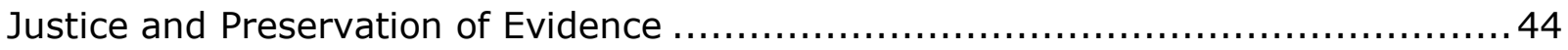

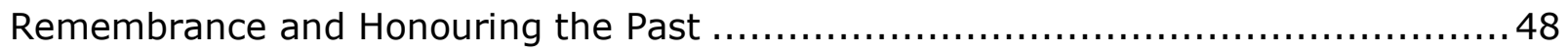

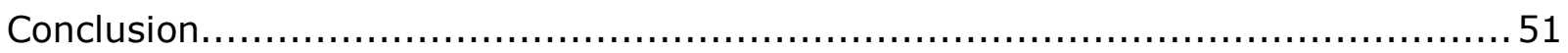

CHAPTER 3: CONSTRUCTING AND REPRESENTING VICTIMHOOD IN

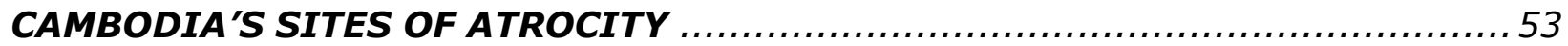

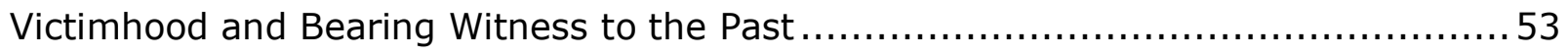

Victimhood and Representing Victims' Voices ....................................... 56

Victimhood and Representing a Complex Past....................................... 60

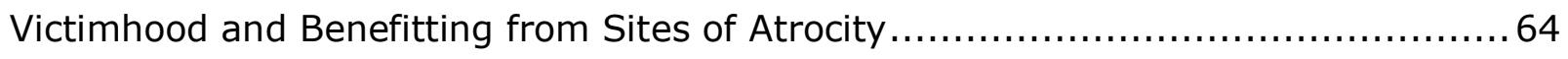

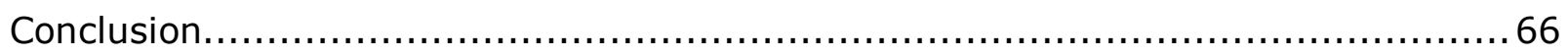

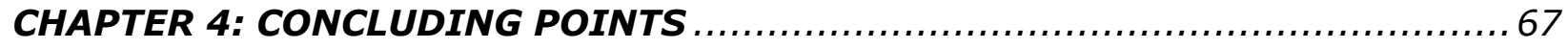




\section{EXECUTIVE SUMMARY}

\section{INTRODUCTION}

The practice of 'dark tourism', whereby members of the public visit sites associated with atrocity and violence, has received growing attention in recent years. Thousands of visitors travel to Auschwitz, Robben Island, ports used in the global slave trade, and to other sites of mass atrocity. Yet, despite the pages dedicated to dark tourism in travel guides, surprisingly little is known about how victims' voices are represented and the extent to which those most directly affected by violence have been able to contribute to the story that is told in these places. Focusing on sites of atrocity in Cambodia, including the Tuol Sleng Museum of Genocide and Choeung Ek Genocidal Centre, this research project sought to address this gap.

The research team are based at Queen's University Belfast and spent two weeks conducting interviews with victims and survivors of the Khmer Rouge regime, staff from the Extraordinary Criminal Courts of Cambodia (ECCC), site managers, members of local non-governmental organisations and others. We also undertook site visits to Tuol Sleng, Choeung Ek, Kampong Chhnang Airfield and Kraing Ta Chan Peace Centre, as well as visiting other sites associated with violence during the regime. Throughout, our objective was to explore how victims of the Khmer Rouge regard the public- and touristfacing focus of Tuol Sleng and Choeung Ek, how specific victims' voices and experiences were chosen for public display and to what extent are victims and survivors able to retain ownership over their experiences and narratives. Our findings can be divided into the following key areas: acknowledgement and truth; education and guarantees of non-repetition; healing, justice and preservation; remembrance and honouring; bearing witness to the past; representing victims' voices; representing a complex past; and benefitting from sites of atrocity. 


\section{ACKNOWLEDGEMENT AND TRUTH}

The research revealed the importance of Cambodia's sites of atrocity as spaces for the recovery of truth about, and acknowledgement of, past harms. The importance of 'letting the world know' what happened in Cambodia was emphasised by a number of interviewees. Interviewees highlighted how truth and acknowledgement can be realised in different ways at the sites. For example, at Tuol Sleng, the photographs of former detainees have been used by surviving relatives to search for loved ones. In contrast, at Kampong Chhnang Airfield, where less has been done to preserve the site, the vast expanse of concrete and remaining buildings exist as testimony to the forced labour which occurred there.

\section{EDUCATION AND GUARANTEES OF NON-REPETITION}

Our interviewees spoke of the value of these sites in terms of educating people about: the history of the Khmer Rouge regime, what life was like under the regime, and the specific harms perpetrated at the sites. A number of interviewees spoke of how this learning happened at two levels. Firstly, directly by those visiting the sites and secondly, by visitors communicating what they had learned to others. This function was considered beneficial for young Cambodians, survivors and international visitors. Crucially, education was also viewed as a 'Guarantee of Non-Repetition.' Interviewees hoped that learning about the Cambodian case could contribute to genocide prevention on a global scale.

\section{HEALING}

A further function of the sites discussed by interviewees was emotional, mental, psychological and spiritual healing. This was experienced both directly - through the use of the sites for therapies, visiting and lighting of incense, and through using these sites as a space to talk about the past - and indirectly, as survivors see visitors coming to the sites to remember and respect the dead. Several interviewees also spoke of encounters between former cadres and victims of the regime at Tuol Sleng and other former prison sites in the 
provinces. This may suggest that the sites are spaces for potential reconciliation activity.

\section{JUSTICE AND PRESERVATION}

The themes of justice and preservation had a number of meanings for interviewees. First is in respect to criminal evidence and the preservation of the physical artefacts of the Khmer Rouge period. These include buildings and structures, human remains, tools and weapons used for torture, the clothing of victims, and written documents and photographs. The trials of Duch, Nuon Chea and Khieu Samphan at the ECCC have all used evidence gathered at Tuol Sleng, Choeung Ek, Kampong Chhnang Airfield and Kraing Ta Chan Peace Centre. Second was the importance of preserving the physical structures of the past to help educate younger generations about the reality of life under the Khmer Rouge. Third was the desire to ensure that the past is not forgotten.

\section{REMEMBRANCE AND HONOURING}

Memorialising victims, and honouring the past, were highlighted by many interviewees as important purposes of the sites. Key factors included honouring and dignifying the dead, through for example, using the sites as places of prayer, the lighting of incense, and respectful contemplation. The role of the sites as locations for remembrance events and community memory initiatives was also considered important.

\section{BEARING WITNESS TO THE PAST}

One of the clearest themes across many of the interviews undertaken by the research team was the importance to victims and survivors of being able to tell the 'story' of life and victimisation under the Khmer Rouge regime. Indeed, a number of survivors described themselves as a 'living document' of that period of time. Within this theme of 'bearing witness to the past', we identified three areas of importance - bearing witness to the past within and beyond Cambodia; the therapeutic value of sharing details of the past; and the preservation of memory. 


\section{REPRESENTING VICTIMS' VOICES}

The importance placed by our interviewees on hearing and representing victims' voices attests to the fact that the representation of a plurality of voices has not yet been fully realized at the sites. A number of overlapping areas were identified amongst interviewees, including the relationship between telling 'the story' and acknowledgment and empowerment, and the importance of including victims and survivors in the development of the sites.

\section{REPRESENTING A COMPLEX PAST}

A broad understanding of victimhood was articulated by our interviewees. This included recognition of the fluidity of victimhood and the fact that many Khmer Rouge cadres were also victims of the Khmer Rouge, and as such, should be considered victims of that period. It also encompassed the range of harms that were experienced during the Khmer Rouge regime. In addition to mass murder and torture, forced labour, starvation and sexual violence were widespread across Cambodia and should be recognised as harms of the regime.

\section{BENEFITTING FROM SITES OF ATROCITY}

Three key points were made by interviewees as to how victims and survivors might benefit from Cambodia's sites of atrocity: the promotion of solidarity, developed through social and therapeutic initiatives around the sites; the capacity of international tourists to acknowledge and 'validate' the experience of survivors; and the suggestion that victims and survivors might benefit financially from the income generated by Tuol Sleng and Choeung Ek. 


\section{RECOMMENDATIONS}

In the conclusion, we make the following practical recommendations that sites of dark tourism might adopt to ensure a sensitive and inclusive recognition of victimhood.

- Access: It is important that survivors of past violence have the opportunity to visit sites connected to their experience. Facilitating this may involve providing resources to facilitate access and psychological and emotional support for survivors when there. Schemes which facilitate young people visiting sites may be appreciated and valued.

- Preservation and Authenticity: Where possible, resources should be made available to preserve a range of sites. Care should be taken that authenticity is maintained where possible, and the addition of elements such as reconstructions or artefacts from other sites should be clearly signposted.

- Inclusion: The best way to ensure that the needs of victims and survivors are met with regards these sites is to include them in discussions around their preservation, development, and design. Providing opportunities for survivors to tell their stories can also be appreciated.

- Recognition and Representation: The development of a range of sites of past atrocity, the inclusion of a diversity of victims' experiences, and engagement with the full range of harms suffered is the best way to ensure that the experiences of past violence are accurately represented.

- Education: Developers and managers of dark tourist sites might wish to consider ways in which an educational role can be enhanced, for example by providing spaces for reflection, posing questions for visitors to consider and increasing opportunities for visitors to engage with survivors. If possible, a focus on genocide prevention could be incorporated.

- Respect and Sensitivity: It is important that visitors behave in a respectful way. Visitor guidelines can be helpful in ensuring this, as can providing areas for peaceful reflection. Developers and managers should also be mindful that over-commercialisation, for example through the inclusion of souvenir shops, might be deemed disrespectful by survivors. The overarching principles of respect and sensitivity should be observed. 
INTRODUCTION: VICTIMHOOD AND DARK TOURISM IN CAMBODIA

The Communist Party of Kampuchea, also known as the Khmer Rouge, held power in Cambodia from April 1975 - January 1979. Their aim was to liberate Cambodia from historical foreign influences, abolish private property and currency and establish a new idealised agrarian nation. This new life would involve communal living and eating; forced, arranged marriages; no religion or ritual; no healthcare; and a vision of education through work. ${ }^{1}$ In the quest to achieve their ideals, the Khmer Rouge enacted a series of policies that led directly or indirectly to the deaths of approximately 1.7 million citizens. Deaths were the result of extreme exhaustion, disease, starvation, torture, murder and execution. ${ }^{2}$

One of the defining features of the Khmer Rouge regime was the establishment of security centres across Cambodia for the detention and torture of suspected enemies of the regime, and the subsequent creation of mass graves. The best known of these sites are Tuol Sleng and Choeung Ek. Tuol Sleng, or S-21, is a former high school in Phnom Penh, converted by the Khmer Rouge in 1976 into an interrogation centre. Tuol Sleng is the Khmer Rouge's most notorious prison, though by no means its largest. ${ }^{3}$ An estimated 14,000 men, women and children were detained and tortured at Tuol Sleng. Only 14 are known to have survived. Nearby is Choeung Ek, a Chinese graveyard appropriated by the Khmer Rouge in 1977 to act as a site of execution and burial location for the bodies of detainees from Tuol Sleng and those who lived in the surrounding areas. An estimated 14,000-17,000 are buried at Choeung Ek in a total of 129 mass graves.

Today, many markers of Cambodia's violent past remain on the landscape. They include former wats and schools, converted by the Khmer

\footnotetext{
${ }^{1}$ Kiernan, B. (2008). The Pol Pot Regime: Race, Power and Genocide in Cambodia under the Khmer Rouge, 1975-79. $3^{\text {rd }}$ ed. New York: Yale University Press.

2 Hinton, A. (2004). Why Did They Kill? Cambodia in the Shadow of Genocide. California: University of California Press.

3 Bennett, C. (2015). To Live Amongst the Dead: An Ethnographic Exploration of Mass Graves in Cambodia. University of Kent: Unpublished PhD thesis. Copy on file with authors.
} 
Rouge into security centres and warehouses; massive reservoirs and irrigation systems; nearly 400 mass graves; and many thousands of individual graves. ${ }^{4}$ Increasing attention has been paid to the transformation of former sites of atrocity into places for international tourists to visit and learn something of the country's past. The Tuol Sleng Museum of Genocide and Choeung Ek Genocidal Centre have been used in this way. This is not uncommon in other post-conflict societies, where the practice of visiting former sites of violence, victimhood and death has become known as 'dark tourism'. For example, in Poland, Auschwitz concentration camp, built and operated by Nazi Germany during World War Two receives over 1 million visitors each year. Likewise, in South Africa, Robben Island - which was used by the South African government as a prison for political prisoners and convicted criminals during apartheid - was visited by approximately 380,000 tourists in 2017.

4 Tyner, J. (2016). Landscape, Memory and Post-Violence in Cambodia. London: Rowan and Littlefield. 


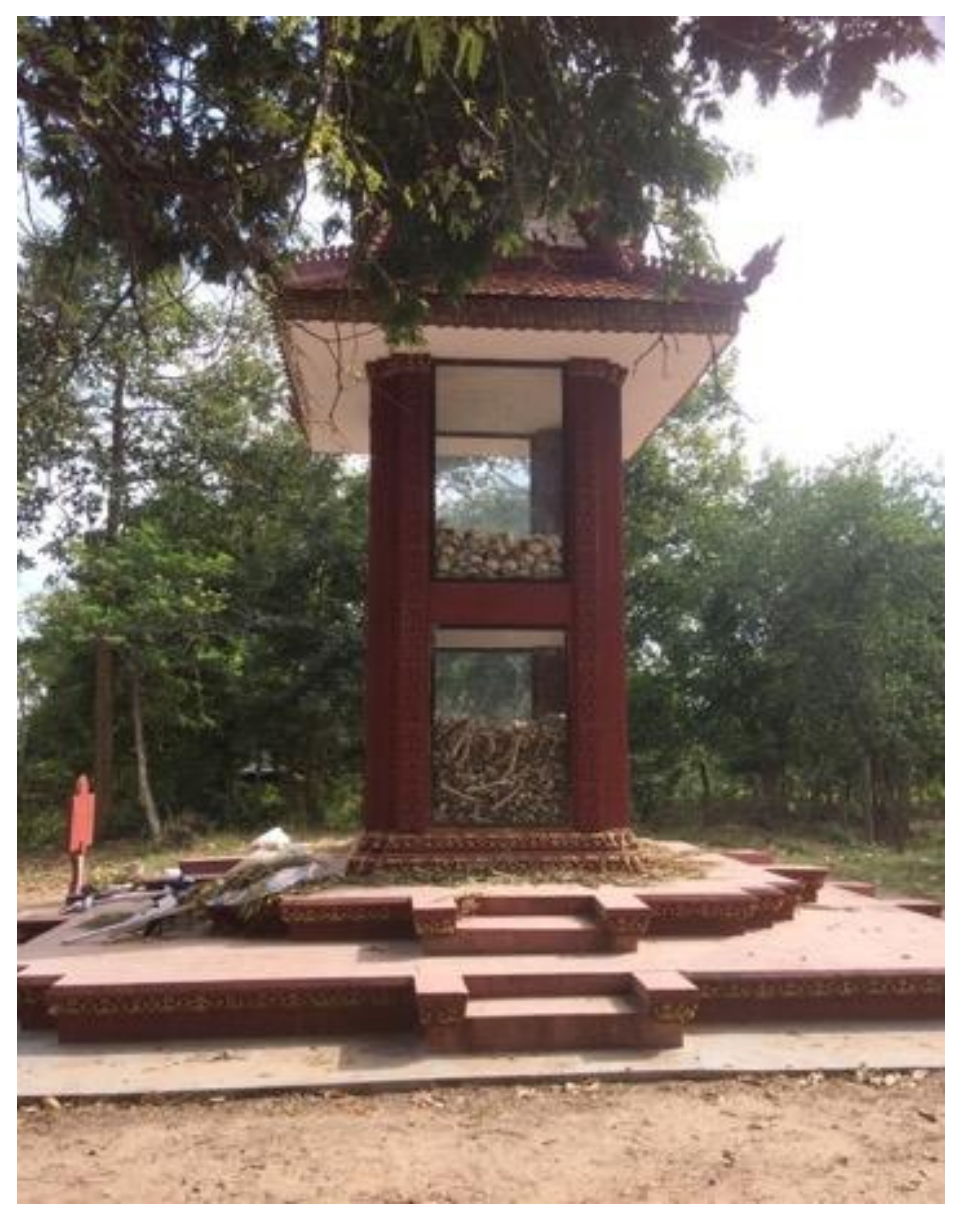

Figure 1: Stupa at mass grave site, Porpe Phnom

However, while researchers and others have paid attention to how tourists experience former sites of atrocity, comparatively little attention has been paid to how victims' voices are represented and the extent to which those most directly affected by violence have been able to contribute to the stories that are told in these sites. Focusing on Cambodia, this research project - 'Whose Voices are Heard? Victimhood and Dark Tourism in Cambodia' - sought to address these questions. The research team are based at Queen's University Belfast in Northern Ireland and funding was provided by the Department for Education (Northern Ireland) - Global Challenges Research Fund (GCRF). The Global Challenges Research Fund is a United Kingdomsponsored programme that seeks to address challenges faced by developing countries. One of the GCRF's key themes is the promotion of human rights, good governance and social justice. In Cambodia, our project partner was the Documentation Centre of Cambodia (DC-Cam), an independent Cambodian research institute with a reputation as a leader in the quest for memory and justice. DC-Cam provided advice on all aspects of the project, including 
helping to facilitate interviews and site visits and providing local logistical support.

The research team spent two weeks in Cambodia in January 2018. Our work was guided by 5 key questions:

1. How do victims of the Khmer Rouge regard the public- and tourist-facing focus of Tuol Sleng and Choeung Ek?

2. How are specific victims' voices and experiences chosen for public display? Are any voices or experiences of the Khmer Rouge period silenced?

3. To what extent do victims retain ownership over their experiences and narratives when they are represented in places like Tuol Sleng and Choeung Ek?

4. How are hierarchies of victimhood created, perpetuated or challenged?

5. Are sites of mass atrocity an appropriate place in which to explore the complexity of who is defined as a 'victim' or 'perpetrator' of conflict?

In total, 32 interviews were completed. Participants included victims and survivors, former Khmer Rouge cadres, staff from the Extraordinary Criminal Courts of Cambodia (ECCC), site managers, local non-governmental organisations, historians, film makers, psychologists and others. This diversity of interviewees helped to inform our understanding of how former sites of violence are used and understood in Cambodia. The research team also undertook site visits to Tuol Sleng, Choeung Ek, Kampong Chhnang Airfield and Kraing Ta Chan Peace Centre, as well as visiting other sites associated with violence during the regime. All of these sites are places of mass atrocity but differ in terms of their visibility and recognition of victimhood. Again, visiting these sites was crucial in helping us to understand the experience of violence and victimhood in Cambodia. Before leaving Cambodia, a preliminary feedback and findings seminar was hosted for approximately 50 DC-Cam staff, local students, international researchers and members of the local community. We are very grateful to the individuals and organisations we visited for their hospitality and to our interviewees for giving up their time so generously and sharing their experiences with us.

This research report details our findings. The report begins by introducing the four sites that form the basis of our findings: Tuol Sleng, Choeung Ek, Kraing Ta Chan, and the Kampong Chhnang Airfield. It then moves on in Chapter Two to exploring how these sites have been used in the aftermath of 
the regime as places of acknowledgment, truth, education, justice, remembrance and reconciliation. In Chapter Three, the analysis focuses on how victimhood is constructed and recognised in the four sites. Where possible, we have allowed the voices of our interviewees - many of whom are victims of the Khmer Rouge, to 'speak'. We have also sought to illustrate our findings through a selection of photographs taken during our time in Cambodia. The conclusion summarises the report's key findings and makes some tentative suggestions as to practices which sites of dark tourism might adopt to ensure a sensitive and inclusive recognition of victimhood. 
In this chapter, we introduce the four field sites we visited during our time in Cambodia: the Tuol Sleng Museum of Genocide, Choeung Ek Killing Fields, Kraing Ta Chan Peace Learning Centre, and the Kampong Chhang Airfield. In order to provide context to our findings in Chapters Two and Three, this chapter provides an overview of what occurred at the sites during the Khmer Rouge regime, as well as how the sites are used now and who visits them.

THE TUOL SLENG MUSEUM OF GENOCIDE AND CHOEUNG EK KILLING FIELDS

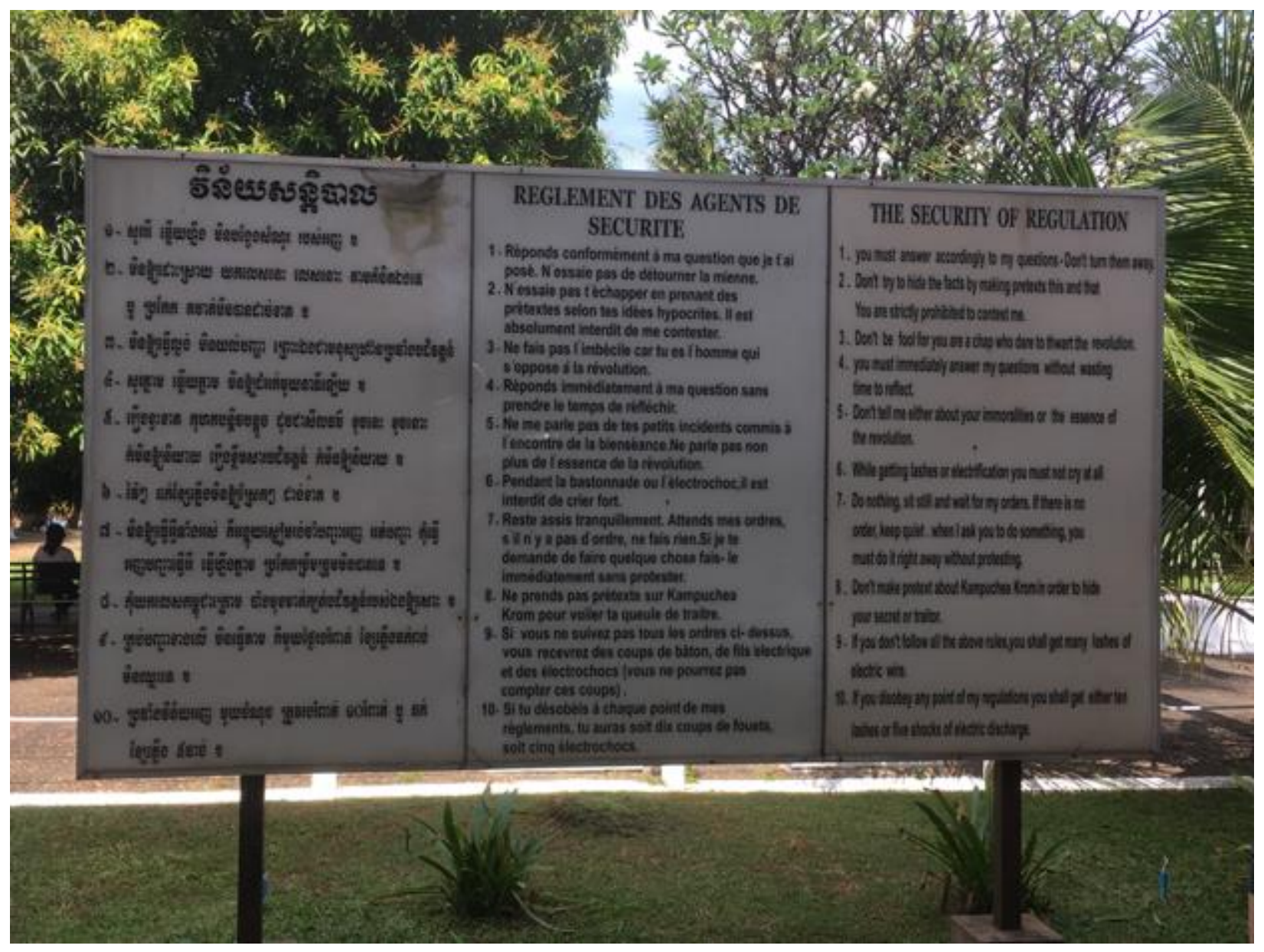

Figure 2: Rules for S-21 detainees, on display inside Tuol Sleng Museum of Genocide 


\section{WHAT HAPPENED THERE?}

The first site the team visited was the Tuol Sleng Museum of Genocide. A former high school situated in central Phnom Penh, this museum was known as ' $\mathrm{S}-21$ ' during the Khmer Rouge regime and is the most well-known of the regime's security centres. At least 12,000 people were held at the site, ${ }^{5}$ where they were subjected to interrogation and torture. Prisoners were Khmer Rouge Party members and combatants who had been identified as 'traitors', as well as their families, including children. Only 14 individuals are known to have survived. We met with survivors of the site who spoke of 'electric shocks, pulling out the nail, drowning, starvation...and how the Khmer Rouge forced us to lick the human defecation. ${ }^{16}$ The team also visited the related Choeung Ek Killing Field, a former orchard $6 \mathrm{~km}$ outside Phnom Penh where victims of Tuol Sleng were taken to be killed, leading to the creation of approximately 129 mass graves contained within the 6 hectares around the site.

Both Tuol Sleng and Choeung Ek are crime sites in Cases 001 and 002 before the Extraordinary Chambers in the Courts of Cambodia. In 2012 the ECCC upheld the conviction of Kaing Geak Eav (alias Duch), the former Chairman of S-21, for crimes against humanity and grave breaches of the Geneva Conventions of 1949.7 In 2018 the Trial Chamber found NUON Chea and KHIEU Samphan guilty of crimes against humanity committed at the sites. They highlighted the deplorable detention conditions, lack of procedural safeguards, and multiple interrogation methods used at S-21, and estimated that at least 11,742 prisoners were executed at or in the vicinity of S-21 and Choeung Ek and buried in mass graves. ${ }^{8}$

${ }^{5}$ Case 001, Trial Judgment, 001/18-07-2007/ECCC/TC, 26 July 2010, para. 23.

${ }^{6}$ Interview 2, 6 January 2018.

7 Case 001, Appeal Judgement, 001/18-07-2007/ECCC/SC, 3 February 2012.

8 Case 002/02, Summary of Judgement, 002/19-09-2007/ECCC/TC, 16 November 2018, para. 21. 


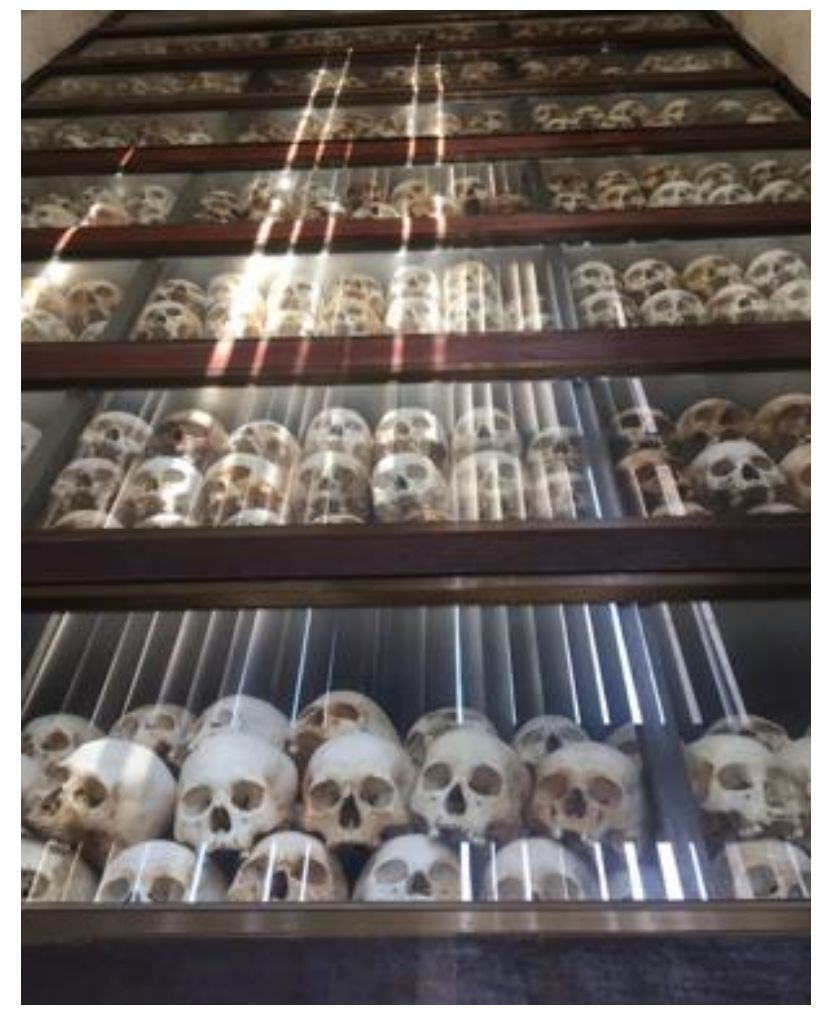

Figure 3: Skulls inside the stupa at Choeung Ek Killing Fields

\section{HOW ARE THE SITES USED NOW?}

The Tuol Sleng Museum of Genocide was opened in 1979, less than three months after the Khmer Rouge were driven from Phnom Penh, and has been open ever since. It is currently under the remit of the Royal Government of Cambodia's Ministry of Culture and Fine Arts. The site comprises five buildings surrounding a grassy courtyard. Some of the buildings' rooms have been left to appear as they were found in 1979, allowing visitors to stand in the cells used to detain prisoners. Other rooms have been developed to house the infamous photos of S-21's many victims, as well as temporary and permanent exhibitions about the regime and Buddhist memorials to the dead. The compound also contains 14 graves which commemorate the last 14 victims of S-21, a memorial stupa listing the names of S-21's victims, office buildings, a gift shop, and stalls at which three survivors sell books detailing their experiences. Since 2015, the Museum has also had a meditation room called the White Lotus Room, where visitors can spend time in reflection, an Activity Room for secondary and high school students to learn about the Khmer Rouge 
regime, and a Testimony Program which allows visitors to meet with survivors of the regime and hear their experiences. Visitors are given the option of an audio guide, which provides background information about the Khmer Rouge regime, discusses what can be found within each building, details the crimes that were committed there, and plays excerpts of survivors and former security guards discussing their experiences of the site. The Museum is also an archive, much of which has been registered as part of the Memory Register of the World by UNESCO since 2009. The Museum's website describes it as a 'living museum and a source of primary materials for researchers' and details the Museum's commitment to promoting greater understanding of the Khmer Rouge period. ${ }^{9}$ The Museum has four pillars which underpin its approach: reflection, education, remembrance, and justice and healing.

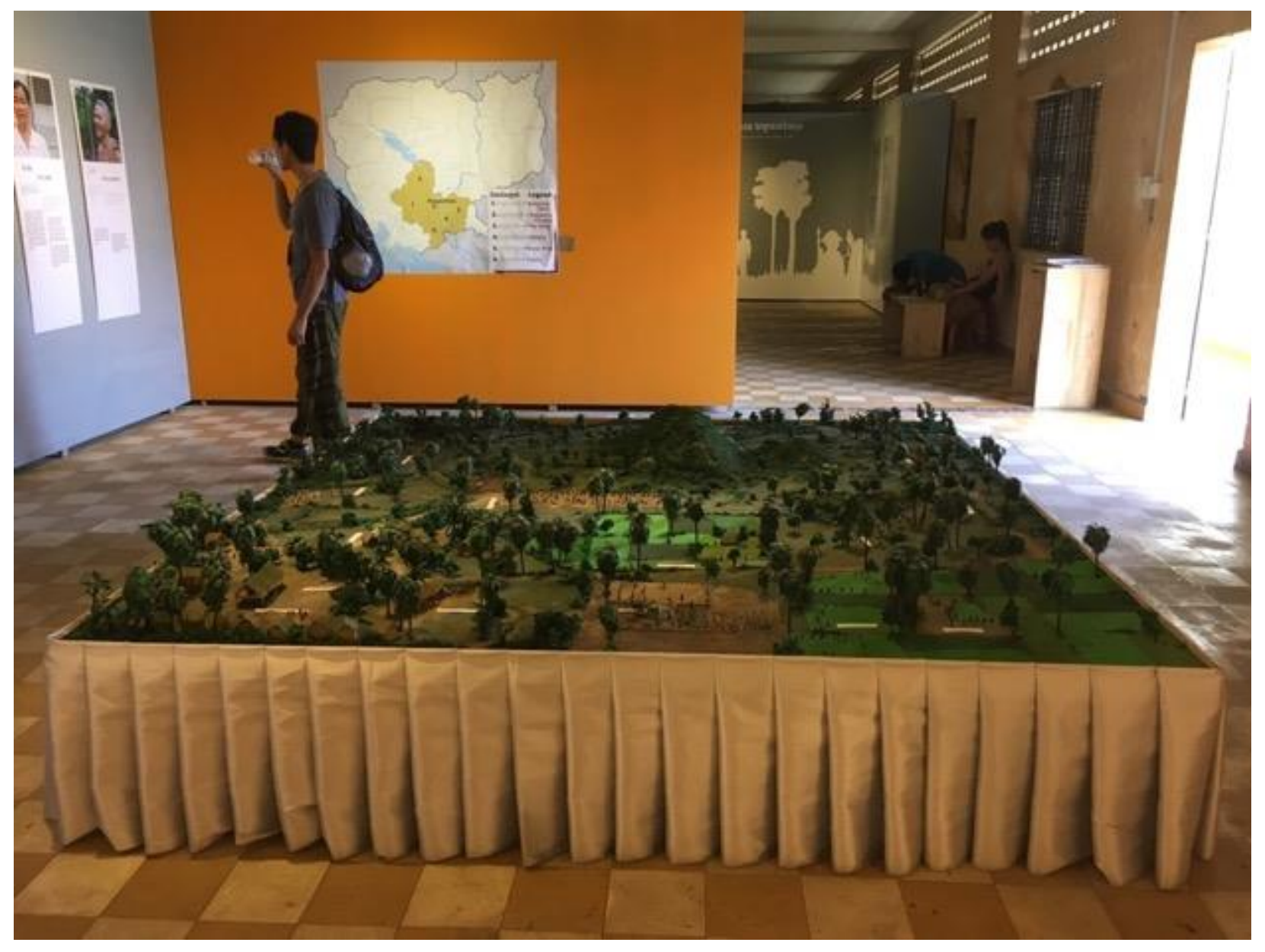

Figure 4: Temporary exhibition in Tuol Sleng Museum of Genocide

${ }^{9}$ http://tuolsleng.gov.kh/en/education/ 
The Choeung Ek Killing Field is managed by a private Japanese company called JC Royal, who claim to have established a non-profit organisation to manage the site, with a proportion of the entrance fees going to charity. The focal point of the site is a large stupa, constructed by the Royal Government of Cambodia in 1988 to house the remains of nearly 9,000 skeletons exhumed from the site. This concrete stupa contains 17 levels, with the remains labelled and organised by bone type. Choeung Ek also includes a museum and a guided walk which takes the visitor round a number of tragic sites, including a grave of decapitated victims, a grave of women, a tree at which young children were murdered and collections of victims' clothes. As with Tuol Sleng, visitors are given the option of an audio tour, which provides more background information about the Khmer Rouge, details of the crimes which occurred at Choeung Ek, stories from survivors of the regime, and information about the stupa. The museum, which has not been updated in many years, outlines the structure of the Khmer Rouge regime, provides details as to the regime's senior leaders, displays photos of life during the regime and confessions from victims of Tuol Sleng, and contains cabinets displaying torture implements. It also contains some outdated information about the Extraordinary Chambers in the Courts of Cambodia. Members of staff from Choeung Ek have described the site's purpose as being to preserve the 'historical evidence of what happened' and to 'show the world the sadness and suffering of the Khmer people'. ${ }^{10}$

\section{WHO VISITS THE SITES?}

The Tuol Sleng Genocide Museum and Choeung Ek Killing Fields are now popular tourist destinations, particularly among international visitors to Cambodia. They are almost certain to be listed in Cambodia's top tourist attractions on travel websites and are a frequent suggestion of local tour guides and tuk tuk drivers. Amongst our interviewees, the sites were seen as having originally been designed for both local and international visitors, but as having been primarily marketed at international visitors in recent years. ${ }^{11}$

\footnotetext{
${ }^{10}$ Interview 2, 9 January 2018; Interview 2, 12 January 2018.

${ }^{11}$ Interview 2, 8 January 2018; Interview 2, 5 January 2018.
} 
However, several organisations spoke of running outreach events and other programmes which brought both survivors and young people to the sites, ${ }^{12}$ with several hundred Khmer visitors coming to the sites each week through these programmes. ${ }^{13}$ Therefore, while Khmer audiences were visiting the sites, very few appeared to be independent visitors. This was explained as being for a number of reasons, ranging from people having no wish to relive violent periods of history, ${ }^{14}$ to wishing to go but not having the financial ability, ${ }^{15}$ to having previously visited and having no need to go again, ${ }^{16}$ to having no need to see the sites as they were able to visit crime sites within their own communities. ${ }^{17}$ However, it was noted that the actual number of local visitors was difficult to estimate, as only international visitors were required to pay, meaning there was no way of tracking the number of Khmer visitors attending each day. ${ }^{18}$

The continued popularity and development of Tuol Sleng and Choeung Ek as tourist destinations invites reflection on why certain former sites of atrocity are developed in this way while others are not. Amongst our interviewees, one dominant view was that the development of one site over another was down to geographical positioning. Simply, the proximity of Tuol Sleng and Choeung Ek to Phnom Penh made them obvious tourist attractions. ${ }^{19}$ Furthermore, both sites had been the subject of preservation measures by the Vietnamese soon after the fall of the Khmer Rouge, allowing them to be protected against deterioration. In contrast, many of the several hundred other security centres and prisons have either been reclaimed for alternative uses or abandoned. ${ }^{20}$ This was observed by interviewees, who noted that 'there were some very interesting prisons but they have disappeared', ${ }^{21}$ so it was unclear whether 'you could have made memorials of

\footnotetext{
12 Interview 1, 11 January 2018.

13 Interview 2, 12 January 2018.

${ }^{14}$ Interview 2, 10 January 2018.

15 Interview 2, 8 January 2018.

16 Interview 1, 8 January 2018.

17 Interview 1, 8 January 2018; Interview 2, 8 January 2018.

18 Interview 1, 5 January 2018.

19 Interview 1, 5 January 2018; Interview 2, 9 January 2018; Interview 1, 11 January 2018; Interview 1, 8 January 2018; Interview 1, 9 January 2018.

20 'List of Democratic Kampuchea Prison', Documentation Centre of Cambodia, 5 January 2005, available at www.d.dccam.org/Projects/Maps/Mass Graves Study.htm (accessed 20/02/19).

${ }^{21}$ Interview 4, 9 January 2018.
} 
prisons like you could with Tuol Sleng'. ${ }^{22}$ Distance from Phnom Penh was also highlighted as an issue, as 'until the roads got built out ten years ago, there really wasn't an option to develop other sites because there was no way to get tourists to them or people to them anyhow'. ${ }^{23}$

The importance of Tuol Sleng and Choeung Ek as sites of atrocity was felt by interviewees, who noted that the sites were linked to the deaths of 'high-ranking people', ${ }^{24}$ providing motivation for the development of 'some place to remember the victims'. ${ }^{25}$ As such, their status as tourist destinations was seen as a positive thing, with one interviewee describing them as the 'national sites...the highlight of the nation', ${ }^{26}$ and another opining that the sites 'represent all mass killing sites across the country' ${ }^{27}$ However, interviewees also expressed wishes for other sites to be developed for visitors, and a belief that Tuol Sleng and Choeung Ek could not tell the full story of what happened under the regime on their own. ${ }^{28}$ Yet, while other sites may not have become internationally renowned attractions in the same way as Tuol Sleng and Choeung Ek, it was observed that other sites were being preserved and developed around the country:

Other sites are also being preserved. The same preservation but just no visitors go there, and just the local residents and other villagers in the surrounding area pay the respect to the victims. ${ }^{29}$

Increasingly, other sites were being used for study tours, ${ }^{30}$ and as locations for community learning centres, museums and spaces for dialogue. ${ }^{31}$ During our time in Cambodia, we visited a site that had already been developed in this way, Kraing Ta Chan Peace Learning Centre, and a site that, although undeveloped, was increasingly of interest to tourists: Kampong Chhnang Airfield Construction Site. These are introduced below.

\footnotetext{
22 Interview 1, 22 November 2018.

23 Interview 3, 9 January 2018.

${ }^{24}$ Interview 1, 5 January 2018.

25 Interview 1, 5 January 2018.

${ }^{26}$ Interview 2, 8 January 2018.

27 Interview 1, 9 January 2018.

28 Interview 1, 15 January 2018; Interview 1, 8 January 2018.

${ }^{29}$ Interview 2, 9 January 2018.

${ }^{30}$ Interview 2, 8 January 2018.

${ }^{31}$ Interview 4, 10 January 2018.
} 


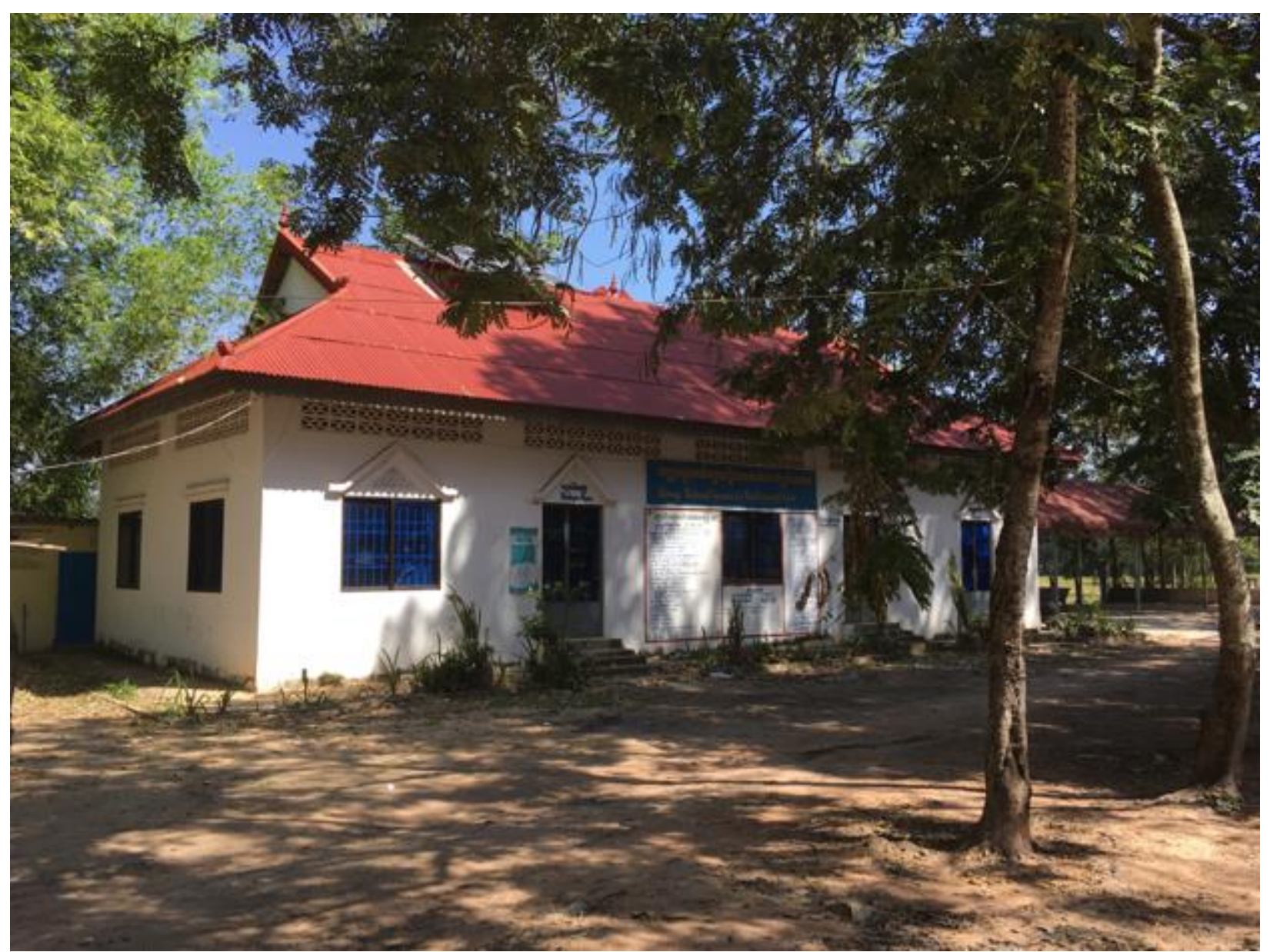

Figure 5: Kraing Ta Chan Community Peace Learning Centre

\section{WHAT HAPPENED THERE?}

Kraing Ta Chan is located in Takeo Province, to the west of Takeo town. Originally established as a Khmer Rouge indoctrination and education centre, Kraing Ta Chan was transformed into a security centre in 1973. The site consisted of a fenced-in compound containing several wooden buildings. These were used to hold and interrogate prisoners and accommodate Khmer Rouge cadres. Whole families were held at the site, and prisoners were shackled day and night unless they were put to work. Interrogations were conducted every day and an estimated 1-3 prisoners died every day, either from being beaten or from starvation, disease or vermin. Victims' bodies were buried around the compound. The site was used during the purges of evacuees 
from Phnom Penh, and it has been estimated that more than 15,000 people were killed at the site. ${ }^{32}$ As observed by one research participant:

Kraing Ta Chan is a remarkable site, I think there are a number of people died and killed, it's also a huge number compared to Tuol Sleng, is similar in number to those killed. ${ }^{33}$

Kraing Ta Chan has also been a crime site in Case 002 before the ECCC. In 2018 the Trial Chamber found that crimes against humanity were perpetrated at the site, highlighting the execution of 'New People' evacuated from Phnom Penh, the violent interrogation methods used at the site, and the use of forced labour. ${ }^{34}$

\section{HOW IS IT USED NOW?}

Kraing Ta Chan was left undeveloped for a number of years. In the early 1980s, the Cambodian People's Party exhumed a number of mass graves, the remains of which were displayed in a memorial stupa on the site. As described by one research participant from the area:

In the past, there were no bones and skulls piled as they were all around in the forest here. Later, mass graves were unearthed by the people in attempt to look for gold...Later, the authority initiated to build a shelter for installing and preserving all of these bones and skulls. It was a lot. Now there is less because dogs came to eat and take these bones away. Seeing so, the authority took an initiative to build the memorial first. This is the only memorial. ${ }^{35}$

In the mid-2000s a Cambodian NGO named Youth for Peace and a committee comprising local community representatives began to construct a Peace Learning Center, which officially opened in 2012. Some information

\footnotetext{
32 Although this was alleged in the Case 002 Closing Order, the ECCC Trial Chamber has since observed that this number is not verifiable, and that they most they can say is that a minimum of 1,000 people were killed there. Case 002/02, Trial Judgement, 002/19-092007/ECCC/TC, 16 November 2018, para. 2807.

${ }^{33}$ Interview 4, 10 January 2018.

34 Case 002/02, Summary of Judgement, 002/19-09-2007/ECCC/TC, 16 November 2018, para. 22.

${ }^{35}$ Interview 1, 13 January 2018.
} 
about the Khmer Rouge period is exhibited in a small museum, and reading resources are contained in another room. A building in the grounds is covered by artwork created by young people which depicts atrocities committed at Kraing Ta Chan - including torture and executions - as well as symbols and motifs of peace, such as white doves. Display boards detailing the site's past use are located around the site, including at the sites of exhumed mass graves. These depict the violence perpetrated at the site, but also the other forms of suffering within the Security Centre, such as starvation.

\section{WHO VISITS THE SITE?}

Kraing Ta Chan has been described as an 'aspiring tourist site', ${ }^{36}$ in that its remote location has limited the ability of visitors to access the site. As observed by one research participant:

If guests want to spend time at Kraing Ta Chan, there's no way to do so. If they want to explore in Kraing Ta Chan, who would take them there?37

Therefore, most visitors to Kraing Ta Chan are either researchers, development workers, staff from Cambodian organisations or participants involved in Youth for Peace's visits to the site. A member of the local committee expressed the wish that the Centre be 'transformed into a tourist site for both national and international visitors' but acknowledged that this was 'not moving' fast. ${ }^{38}$ They also reasserted the importance of showing respect to victims of the site by 'install[ing] their remains, showing their dignity and keep[ing] the past history of the Khmer Rouge for the next generation to know and understand'. ${ }^{39}$

\footnotetext{
36 Henkin, S. (2018). 'Postmemory and the Geographies of Violence at Kraing Ta Chan, Cambodia', GeoHumanities, 4, 2: 462-480.

37 Interview 2, 12 January 2018.

38 Interview 2, 13 January 2018.

39 Interview 2, 13 January 2018.
} 


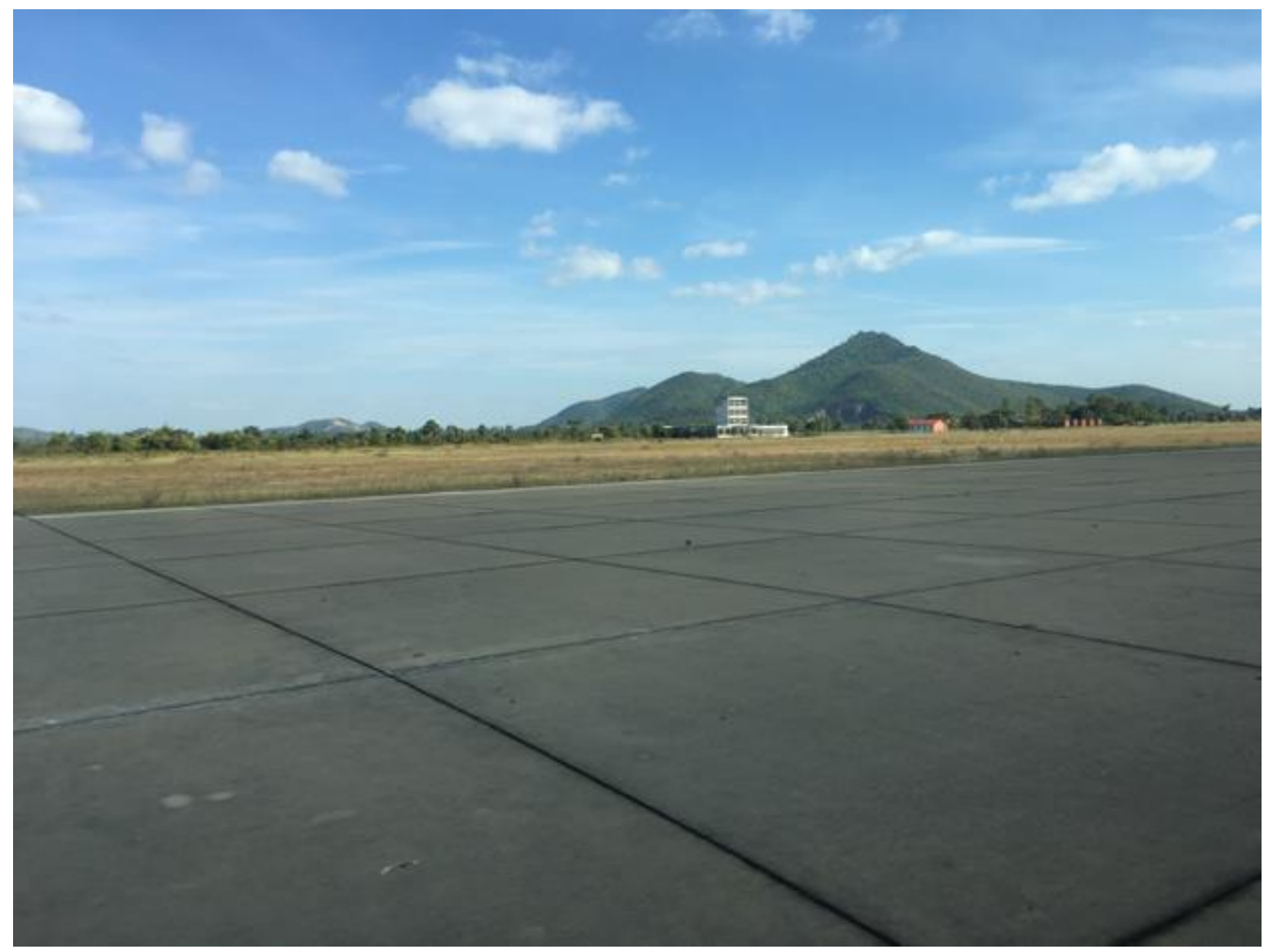

Figure 6: Kampong Chhnang Airfield

\section{WHAT HAPPENED THERE?}

Situated $14 \mathrm{~km}$ west of Kampong Chhnang town, the Kampong Chhnang Airfield Construction Site is a 300- hectare site composed of two 2400-metrelong runways, a control tower and an administration block. The site was under construction from early 1976 until January 1979 but was not completed. The Khmer Rouge would send people believed to be 'bad elements' to work at the site for 're-education purposes', ${ }^{40}$ with the number of workers ranging from a few hundred in 1976 to 10,000 workers by 1977 . Workers at the site were

40 Case 002/02, Summary of the Judgment, 002/19-09-2007/ECCC/TC, 16 November 2018, para 18. 
usually low-ranking soldiers from divisions whose leaders had been sent to Tuol Sleng. The workers were considered expendable, and some were disappeared or sent to Tuol Sleng. Workers were held in slavery and could not refuse to work. They were exposed to unsafe working conditions and were forced to work long hours without sufficient food, resulting in the death of many people. ${ }^{41}$ Thus, the Construction site had two purposes: to create an airport, and to punish individuals targeted for re-education or death. ${ }^{42}$ The Airfield is a crime site in Case 002 at the ECCC, and in 2018 the Trial Chamber found that murder, enslavement, persecution on political grounds, and other inhumane acts of attacks against humanity and dignity and enforced disappearances occurred at the site during the Khmer Rouge era. ${ }^{43}$

\section{HOW IS IT USED NOW?}

Unlike other sites where many people died, there is no stupa containing human remains or memorial at the airfield. We spoke to a survivor of the regime who believed that human remains had been taken elsewhere during the 1990s:

I suspect that all bones and skulls were taken to somewhere else. That site was destroyed and becomes the place of the villagers to live. It was built with wood, but it was all gone. You could see by this. It is visible. The site was in the open air, so it was built for the people to see. It was disappeared after the election probably in $1993 .{ }^{44}$

At the time of the site visit the airfield was completely undeveloped, with the control tower and administration block falling into disrepair. However, there is increasing tourist interest in the airfield, as demonstrated by its inclusion in tuk tuk tours of the area. Research participants spoke favourably of developing the site as a means of teaching people about what happened there, and as a way of survivors developing their knowledge about what happened under the regime. ${ }^{45}$

\footnotetext{
41 Interview 1, 15 January 2018.

42 Interview 1, 15 January 2018.

${ }^{43}$ Case 002/02, Summary of the Judgment, 002/19-09-2007/ECCC/TC, 16 November 2018, para 25.

${ }^{44}$ Interview 1, 15 January 2018.

${ }^{45}$ Author's fieldnotes.
} 


\section{CONCLUSION}

Over two weeks, the research team spent time talking with survivors and community members at each of the four sites described above; these visits and interviews form the basis of the following two chapters. Before moving to discuss our research findings, we would like to reiterate that the sites we visited are only four of many sites of suffering in Cambodia. Across the country, people were detained in security centers, forced to labour in work sites, and were executed and buried in mass graves. The research team were limited by time and resources, and were therefore unable to travel to the many additional sites of atrocity around Cambodia to hear from survivors connected to those sites. We acknowledge that the development of certain sites into tourist destinations over others plays a fundamental role in the stories that are told about the past, and that our analysis is similarly linked to the stories we heard in connection with our chosen sites. We furthermore note that at some sites, such as Porpe Phnom, we were unable to interview survivors and therefore stories linked to this site do not feature in the following chapters. However, we hope that this pilot study can nonetheless contribute to understandings around how victims' voices are represented and the extent to which those most directly affected by violence have been able to contribute to the story that is told in former sites of atrocity. In the following chapter, we begin to explore in greater depth the ways in which former sites of atrocity can function in the aftermath of periods of atrocity, and how the development of sites as tourist destinations intersects with those functions. 


\section{CHAPTER 2: RE-ENVISAGING SITES OF ATROCITY}

Those we interviewed highlighted a range of ways in which the four sites of research as well as other former prison sites and labour camps in the provinces function for survivors of the Khmer Rouge regime, for wider Cambodian society, and for international visitors. In this section these various functions will be analysed, and potential limitations highlighted. These functions are identified as: acknowledgement and truth; education and guarantees of nonrepetition; healing; justice and preservation of evidence; and remembrance and honouring the past.

\section{ACKNOWLEDGEMENT AND TRUTH}

In post-conflict and post-dictatorship contexts around the world, acknowledgment of past harms and the uncovering of truth are argued to be central to attempts to address the suffering of victims. Acknowledgement is what happens to private knowledge when it becomes public knowledge, and this public acknowledgement is of value to some victims. ${ }^{46}$ Acknowledgement is about a recognition of suffering, and also about ensuring that the wider public know the truth of what happened: 'By knowing what happened...and to identify the victims.... is a way of acknowledging their worth and dignity. ${ }^{\prime 47}$ Revealing the truth about the past is an 'onslaught' on silence and denial. ${ }^{48}$ 'The desire for truth,' we are told 'is powerful, and seemingly almost universal. ${ }^{\prime 4}$ This section will examine how the sites function as places of acknowledgement, truth-telling, and truth-seeking.

\footnotetext{
46 Cohen, S. (1995). 'State Crimes of Previous Regimes: Knowledge, Accountability, and the Policing of the Past', Law \& Social Inquiry, 20, 1: 7-50.

47 Neier, A. (1990). "What Should be Done about the Guilty!", New York Review of Books, cited in Cohen (ibid.) at 37.

48 ibid at 15. See also Hayner, P. B. (2011). Unspeakable Truths: Transitional Justice and the Challenge of Truth Commissions. 2nd Edition. New York; Oxon: Routledge and Roht-Arriaza, N. (2006). 'The New Landscape of Transitional Justice.' In: Roht-Arriaza, N. and Mariezcurrena, J. (eds.) Transitional Justice in the $21^{\text {st }}$ Century. Cambridge: Cambridge University Press. pp. 1-16

49 Hayner, ibid. at 6.
} 
Many interviewees spoke of Tuol Sleng, Choeung Ek and Kraing Ta Chan as places where the harms perpetrated by the Khmer Rouge, and the suffering of their victims, could be acknowledged. The importance of 'letting the world know' what happened in Cambodia was emphasised. ${ }^{50}$ According to one interviewee, the sites 'show the world...the sadness and suffering of the Khmer people during the KR regime. ${ }^{151}$ The visiting of Tuol Sleng and Choeung Ek by tourists was seen as a form of acknowledgement of importance to survivors of the Khmer Rouge regime:

people want to be acknowledged, you know, about their atrocity, about the crimes, about their sufferings. Once they have been acknowledged... they feel like having support on that. ${ }^{52}$

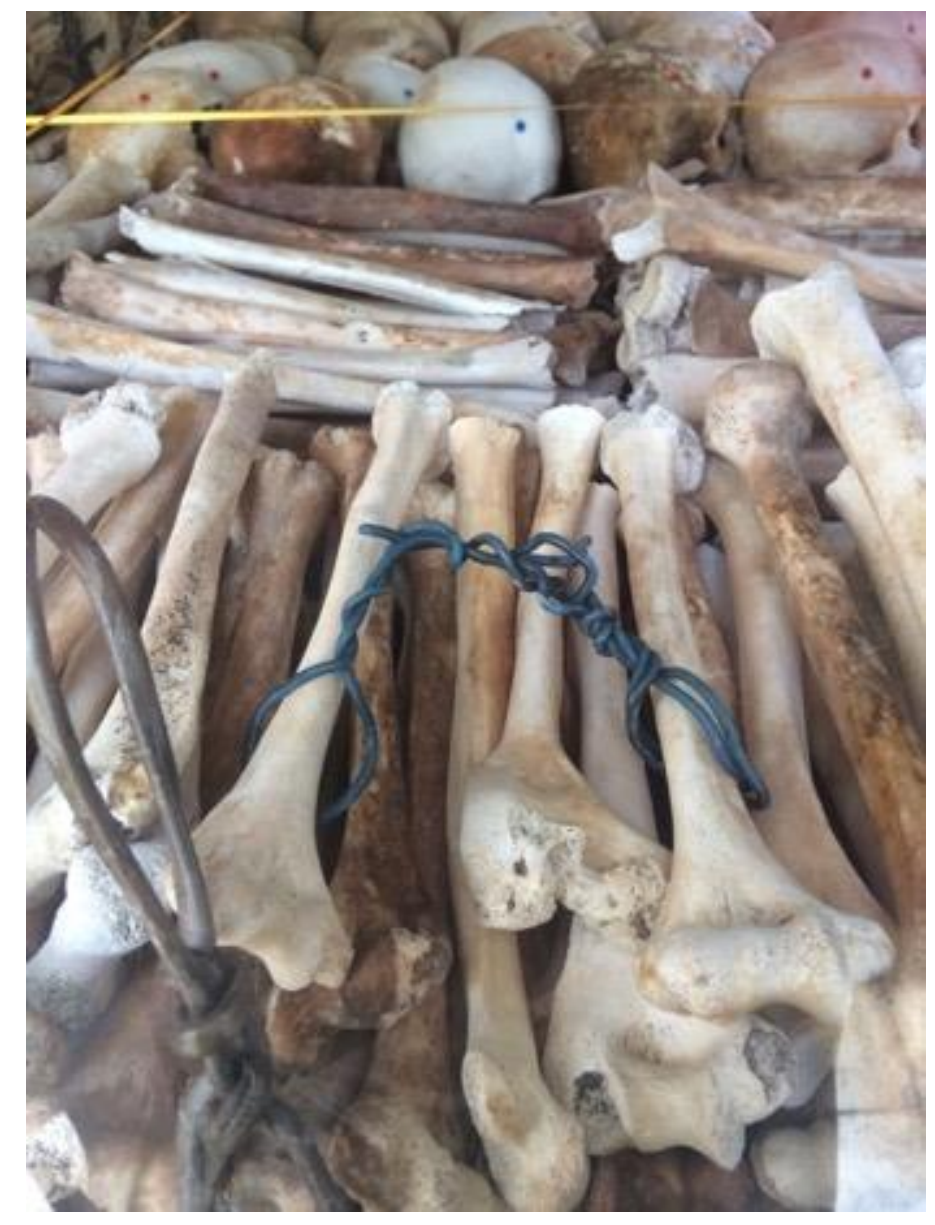

Figure 7: Bones with shackles displayed at Choeung Ek Killing Fields

\footnotetext{
50 Interview 2, 12 January 2018.

${ }^{51}$ Interview 2, 9 January 2018.

52 Interview 1, 10 January 2018.
} 
The preserved sites also function as places of truth-telling, places where the truth of what happened is confirmed. As detailed in Chapter 1, at Tuol Sleng, photographs of victims, and the physical remains of detention and torture, such as cells, tools, and weapons are displayed. At Choeung Ek and Kraing Ta Chan, human remains are preserved in a stupa, and visitors can view mass graves, killing sites, and - at Choeung Ek - the clothing of victims. Even at the Kampong Chhnang Airfield, where less has been done to preserve the site, the vast expanse of concrete and remaining building structures exist as testimony to the forced labour which occurred there. As one interviewee described, being at the sites reminds survivors 'of their own experience. It is true. It confirms that it is true. ${ }^{153}$

There is value in these sites being the actual places where violence was perpetrated. As one survivor described, 'this place is the place of my sad story. ${ }^{154}$ It was considered important that these sites show the 'real history. ${ }^{155}$ Another survivor recounted how it is important to him that 'international visitors... know that all stories here are true not fake. ${ }^{156}$ One interviewee spoke of having heard false accounts of the Khmer Rouge period - including that the suffering was not as bad under the regime as people are led to believe, and that all the Khmer Rouge were Vietnamese. ${ }^{57}$ Having these sites as places where the truth of what took place is physically represented is one way of countering denial. For one survivor, the physical remains of Tuol Sleng and the displays of tools and weapons: 'permit the visitors...to witness the truth. ${ }^{158}$ Another spoke of wanting to 'tell the world' the truth. ${ }^{59}$

A further way in which survivors' stories can be shared at the sites is through the selling of their books - this was mentioned as important by a number of interviewees. That visitors to Tuol Sleng can speak to survivors was considered to be of particular value:

\footnotetext{
53 Interview 2, 10 January 2018.

54 Interview 1, 7 January 2018.

55 Interview 2, 9 January 2018.

56 Interview 1, 13 January 2018.

57 Interview 3, 10 January 2018.

58 Interview 2, 16 January 2018.

59 Interview 2, 9 January 2018.
} 
the survivor plays a very important role because they...tell the truth... he can tell what happened to him ...that's the truth being revealed through the victims. That's very important. ${ }^{60}$

At a more practical level, two of the sites we visited play a role in helping survivors to access the truth about what happened to their own family members. Survivors of the regime discussed the value of Tuol Sleng as a place to 'search for the truth. ${ }^{\prime 61}$ One person described how they 'kept searching' for their relative until they 'found her in Tuol Sleng.' ${ }^{\prime 2}$ Another interviewee recounted of visitors to Tuol Sleng, 'the most important thing [is] that the people from the different province that visit S21, some of them, they found their relatives. ${ }^{163}$ This role is specifically acknowledged in Tuol Sleng's audio guide, which features the story of Ouk Neary, a civil party in the ECCC's case against Duch who travelled to Tuol Sleng to find evidence of her father's death. ${ }^{64}$

The research team learned that at Kraing Ta Chan, a book of names of those who had died there has been compiled, in order to assist relatives in finding out information about their loved ones. This suggests that sites in the provinces can serve as useful hubs of information for relatives of those killed.

With regards the purpose of these sites as places of truth, one challenge that was spoken of by a number of interviewees was the importance of telling the stories of all victims, not just those detained at Tuol Sleng and killed at Choeung Ek. One interviewee explained, 'each crime site has a different history ${ }^{\prime 65}$ as there are differences between what took place at Tuol Sleng and what happened at other sites, Tuol Sleng cannot tell the full story (see Chapter 3). As one interviewee described,

truth could come from all angles, from the angle of victims, from ...the top people who prepared the policy of the Khmer Rouge...but also the

\footnotetext{
60 Interview 1, 5 January 2018.

${ }^{61}$ Interview 1, 15 January 2018.

62 Interview 2, 16 January 2018.

${ }^{63}$ Interview 1, 11 January 2018.

64 Her testimony can be viewed on the ECCC website at www.eccc.gov.kh/en/witness-expertcivil-party/ms-ouk-neary (accessed 20/02/19).

${ }^{65}$ Interview 1, 11 January 2018.
} 
implementer like the lower level of the Khmer Rouge. We want to hear from them too. 66

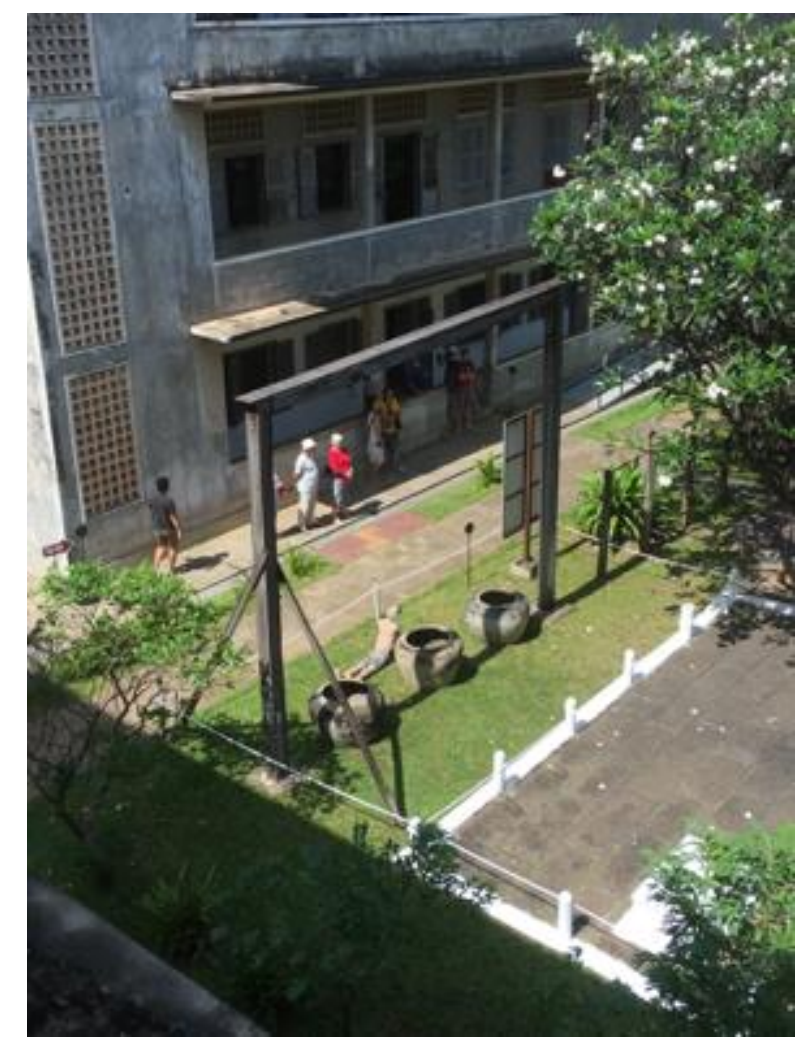

Figure 8: Gallows structure at Tuol Sleng Museum of Genocide

Doubts were raised by some of those we spoke to with regards authenticity. Several interviewees raised concerns about some of the displays at the sites. One particular issue mentioned was the addition of barbed wire to the balconies at Tuol Sleng, which is said not to have been there during the Khmer Rouge period. Another was the presence of a gallows structure in the courtyard in Tuol Sleng, allegedly used to torture inmates. This structure is based on paintings by Vann Nath, but one interviewee noted that victims of Tuol Sleng have claimed that the structure was not there during the regime. ${ }^{67}$ Other interviewees questioned some of the artistic depictions of violent acts while not doubting that they were a true reflection of suffering, there was some uncertainty over the accuracy of paintings in comparison to photographs. One interviewee highlighted that there is a risk that as sites are developed for visitors, authenticity is lost: 'There are so many changes that it

${ }^{66}$ Interview 4, 10 January 2018.

67 Interview 1, 5 January 2018. 
loses its originality. ${ }^{\prime 68}$ One way to ensure that sites maintain authenticity, even as they are developed to facilitate visitors, would be 'to ask the victims and survivors who witnessed all things that happened during their arrest and imprisonment in here', thus enabling those most impacted by past violence to have their voices heard (see Chapter 3). ${ }^{69}$ If changes are made, for example to capture a wider range of experiences, then a caption explaining the change can mitigate against criticisms of inauthenticity.

\section{EDUCATION AND GUARANTEES OF NON-REPETITION}

One of the main purposes of the sites, highlighted by almost all of our interviewees, is education. One interviewee suggested that, as education is such a central purpose of these sites, we should call those who visit 'learners' rather than 'tourists' as 'they come to learn. ${ }^{70}$ In this section, we examine the role of these sites as places of education, and how - for many - this function is considered to be a Guarantee of Non-Repetition (GNR). A GNR is a form of collective reparation aimed at ensuring that violence does not recur. Internationally, these measures can include reform of the judiciary, military or police reform, or education reform including the re-writing of history textbooks, or the provision of education in tolerance and human rights. In countries where attempts have been made to destroy sites where torture was perpetrated, these efforts have been opposed by those who believe that these places should instead be turned into museums to educate people about the past and thus avoid repetition of that past. ${ }^{71}$

Education at the sites takes multiple forms. Those who visit Tuol Sleng and Choeung Ek can learn about what happened there through viewing the exhibits and listening to the audio guides, and they can speak with survivors. Tuol Sleng also contains a reading room in which visitors can find a wide range of resources on the Khmer Rouge and related topics. At Kraing Ta Chan,

\footnotetext{
68 Interview 2, 7 January 2018.

${ }^{69}$ Interview 2, 7 January 2018.

70 Interview 1, 12 January 2018.

${ }^{71}$ See e.g. Firchow, P. (2014). 'The Implementation of the Institutional Programme of Collective Reparations in Colombia,' Journal of Human Rights Practice, 6, 2: 356-375; RohtArriaza, N. (2004). 'Reparations Decisions and Dilemmas,' Hastings International and Comparative Law Review, 27, 2: 157-219.

https://www.ohchr.org/en/professionalinterest/pages/remedyandreparation.aspx
} 
visitors can learn about what happened from the placards which are distributed around the grounds, and from the museum established by Youth for Peace and the local community. Educational programmes are run at Tuol Sleng and Kraing Ta Chan, comprising a variety of activities, 72 and organisations such as Youth for Peace, and the ECCC's Outreach Programme, use the sites as a way of teaching young people and other Cambodians about the Khmer Rouge period. In contrast, the undeveloped site of Kampong Chhnang Airfield provides nothing educational for visitors beyond the physical evidence provided by its existence.

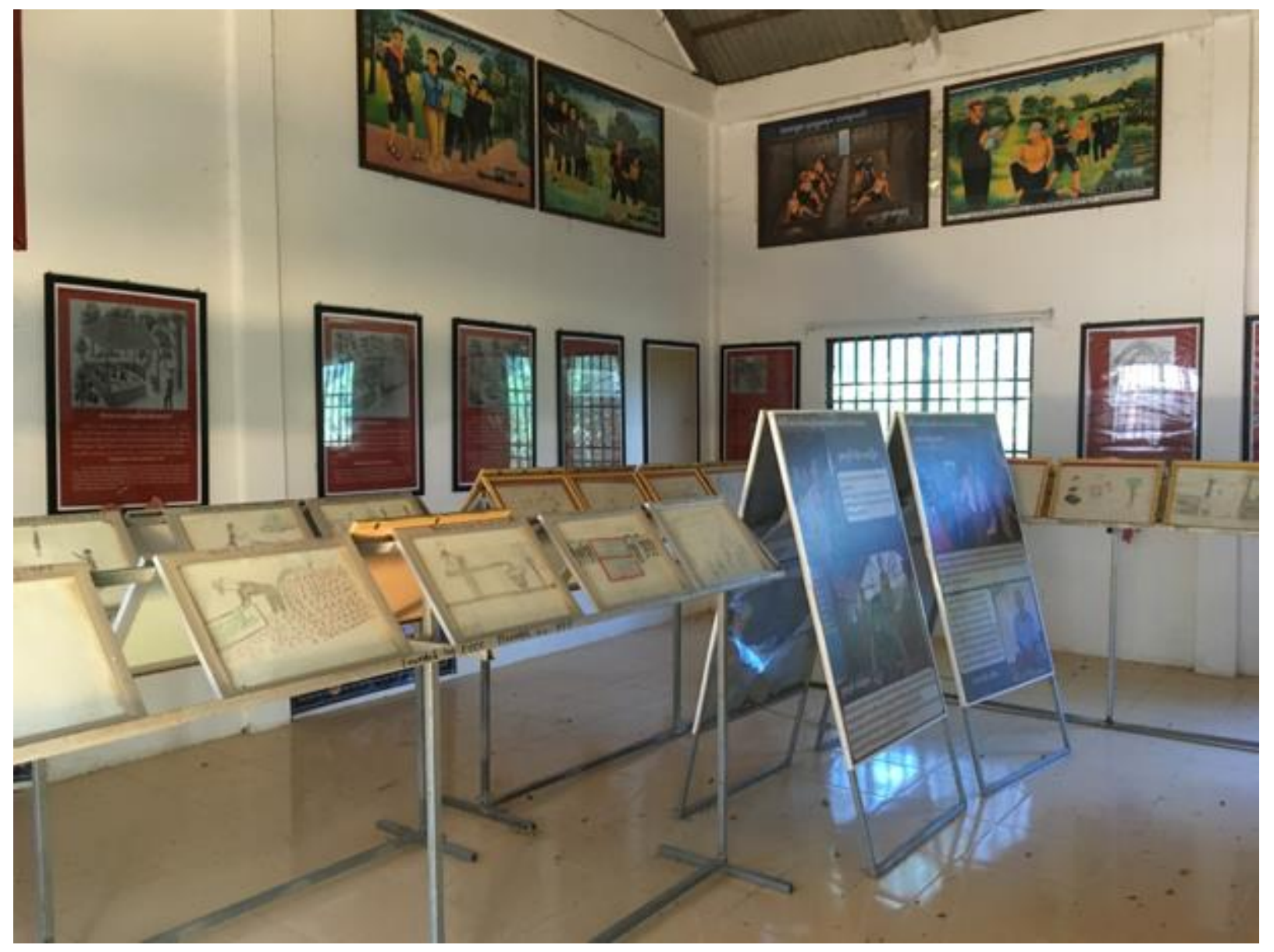

Figure 9: Inside museum at Kraing Ta Chan

Our interviewees spoke of the value of these sites in terms of educating people about: the history of the Khmer Rouge regime, what life was like under the regime, and the specific harms perpetrated at the sites. A number of

72 'Education: Learning Materials for Visitors' http://tuolsleng.gov.kh/en/education/ (accessed 10/05/2019); Interview 2, 13 January 2018. 
interviewees spoke of how this learning happened at two levels. First, directly by those visiting the sites and second, by visitors communicating what they had learned to others: 'the visitors...take the story to tell their children. ${ }^{73}$

This education function was considered to be important for a number of groups. First, for young people, it was suggested that 'sometimes the younger generations who did not live through the regime ...do not acknowledge that it is true. ${ }^{74}$ One interviewee proposed that it is only by visiting the sites that young people can believe what happened: 'what their relatives can tell, they hardly believe until they visit. ${ }^{75}$ Another interviewee suggested that young people 'do believe... but to some extents they don't understand it. "76 For a number of interviewees, it was only through visiting the sites and viewing the physical remains of the Khmer Rouge period that young people could really understand what had happened. In this regard, the sites were seen to give students an opportunity to go beyond what they are taught through school textbooks, and get a sense of the lived reality under the Khmer Rouge regime. One interviewee summarised the value of these sites as:

By educating young people...engaging discussion, interaction... we have many different ways of empowering young people by sharing knowledge, discussion with the survivors, learning from their stories but also, it's a practical way to also see the evidence of what happened, especially at these sites. ${ }^{77}$

One particularly important educational element was the opportunity for young people to speak directly with survivors of the KR regime:

We brought them to not only Tuol Sleng and Choeung Ek, but we brought them to the community and talked to the victims, so they can ask more information and share information with each other. ${ }^{78}$

It was believed to be important to educate young people in particular for several reasons. At the level of family, it was believed to help young people

\footnotetext{
73 Interview 2, 6 January 2018.

${ }^{74}$ Interview 2, 12 January 2018; Interview 2, 11 January 2018.

75 Interview 4, 10 January 2018.

76 Interview 1, 12 January 2018.

77 Interview 4, 10 January 2018.

78 Interview 2, 8 January 2018.
} 
understand how their parents had suffered. ${ }^{79}$ Furthermore, there was a sense that young people could learn more in school about the Khmer Rouge:

what you hear is the young people ...don't really know much about the past and so, it can only help to have these sites where they can...go to places where this actually happened. ${ }^{80}$

At the societal level, as will be analysed later, links were made between educating the young and reducing the chances of violence recurring.

Second, for other survivors, education was also considered to be of importance. As one interviewee described:

they're happy to learn more...because during Khmer Rouge time people were not allowed to travel and people are trained to see only, you know, the one place they're living. So, when they have a chance to understand what's Phnom Penh, another place, they are happy, they appreciate it and they say even it's painful but they still want to know about it. They see it's important. ${ }^{81}$

Third, education was said to be important for international visitors. One interviewee said that the history of the sites must be kept alive as 'all the people in the world have to learn it. ${ }^{82}$

There were several limitations to this education function highlighted during our fieldwork. First, some concern was raised that the ability to learn about the past was limited as some sites have already been damaged or destroyed:

it's not $100 \%$ because...some of them eroded, some of them already destroyed but we still hope that something that remains today can teach other people what happened during the Khmer Rouge. ${ }^{83}$

A second limitation to the education function of the sites is that much of the focus is on violent death, and the opportunities for visitors to learn about the many who died as a result of starvation, overwork, or disease are limited

\footnotetext{
79 Interview 1, 10 January 2018.

${ }^{80}$ Interview 1, 22 November 2017.

81 Interview 2, 10 January 2018.

82 Interview 2, 9 January 2018.

${ }^{83}$ Interview 1, 5 January 2018.
} 
(see Chapter 3). ${ }^{84}$ This relates to the point examined above: Tuol Sleng, Choeung Ek and Kraing Ta Chan are only three sites among 'many others, ${ }^{185}$ and alone do not tell the full story. The desire for other sites to be developed for educational purposes was reflected in the interviews. At the Kampong Chhnang Airport, where nothing has been done to develop the site for visitors, a local survivor of the regime spoke of their wish that the site might be turned into an education site:

I need...the museum for the young generation to learn and know what happened - for the exhibition as information to reach them. If we don't have it...we don't know what happened here. People who come here don't know anything about it. It was built for the killing purpose. ${ }^{86}$

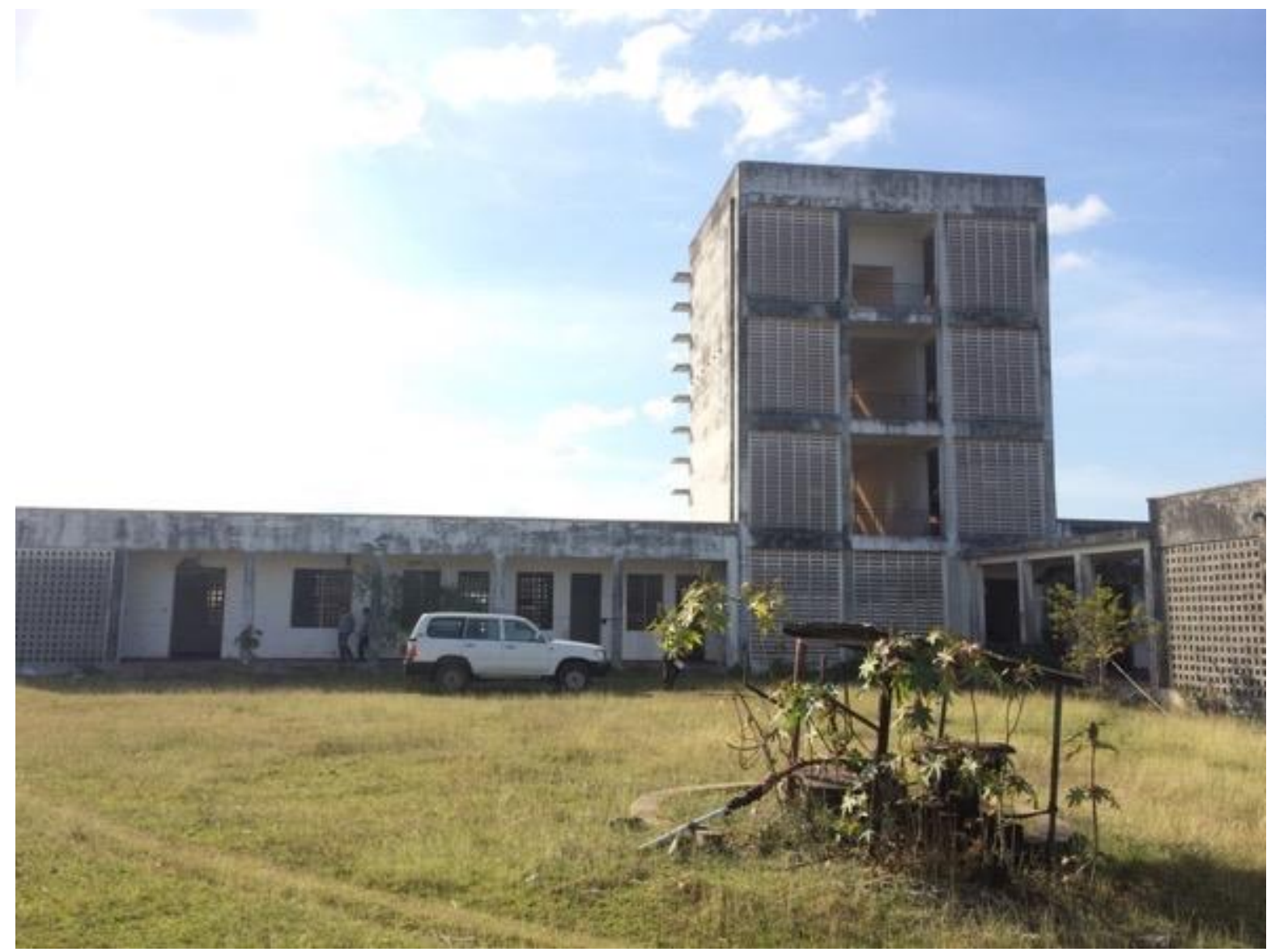

Figure 10: Radio tower at Kampong Chhnang Airfield

\footnotetext{
${ }^{84}$ Interview 1, 15 January 2018.

85 Interview 2, 8 January 2018.

86 Interview 1, 15 January 2018.
} 
Third, some interviewees suggested that more interactive learning could be facilitated at the sites. In their current form, one interviewee suggested, there is a risk that information just washes over young people 'like water over the lotus leaf. ${ }^{87}$ Another said that Tuol Sleng 'doesn't have enough interaction between the visitors...the young people, and the...pictures and so on. ${ }^{\prime 88}$ They emphasised that young people should 'not just go there visit and go back like a resort.' This interviewee continued,

the key message is how we can prevent the genocide... That is the good message and it should be inserted more. ${ }^{89}$

This statement exemplifies a key finding of our research: for many, education was linked directly to non-repetition. From this perspective, by learning about the past, the actions of the Khmer Rouge would not be repeated. This was considered to be important for both young Cambodians and international visitors. As the future leaders of Cambodia, ${ }^{90}$ 'young people play an important role in the prevention of the atrocities from happening again.' 91 One interviewee suggested that the sites 'remind the later generation not to follow what the Khmer Rouge did...Not to let the young follow the dark regime of the Khmer Rouge. ${ }^{192}$ The sites are:

evidence for the later generations to learn from the past [and] not to follow the past mistakes because this path led to the destruction of its own people and nation... That's why the museum and memorial play a role in waking an awareness of the young to see the evidence not to follow the past. ${ }^{93}$

\footnotetext{
87 Interview 2, 10 January 2018.

${ }^{88}$ Interview 2, 8 January 2018

89 Interview 2, 8 January 2018.

${ }^{90}$ Interview 2, 6 January 2018.

${ }^{91}$ Interview 4, 10 January 2018.

92 Interview 2, 14 January 2018.

93 Interview 1, 15 January 2018.
} 


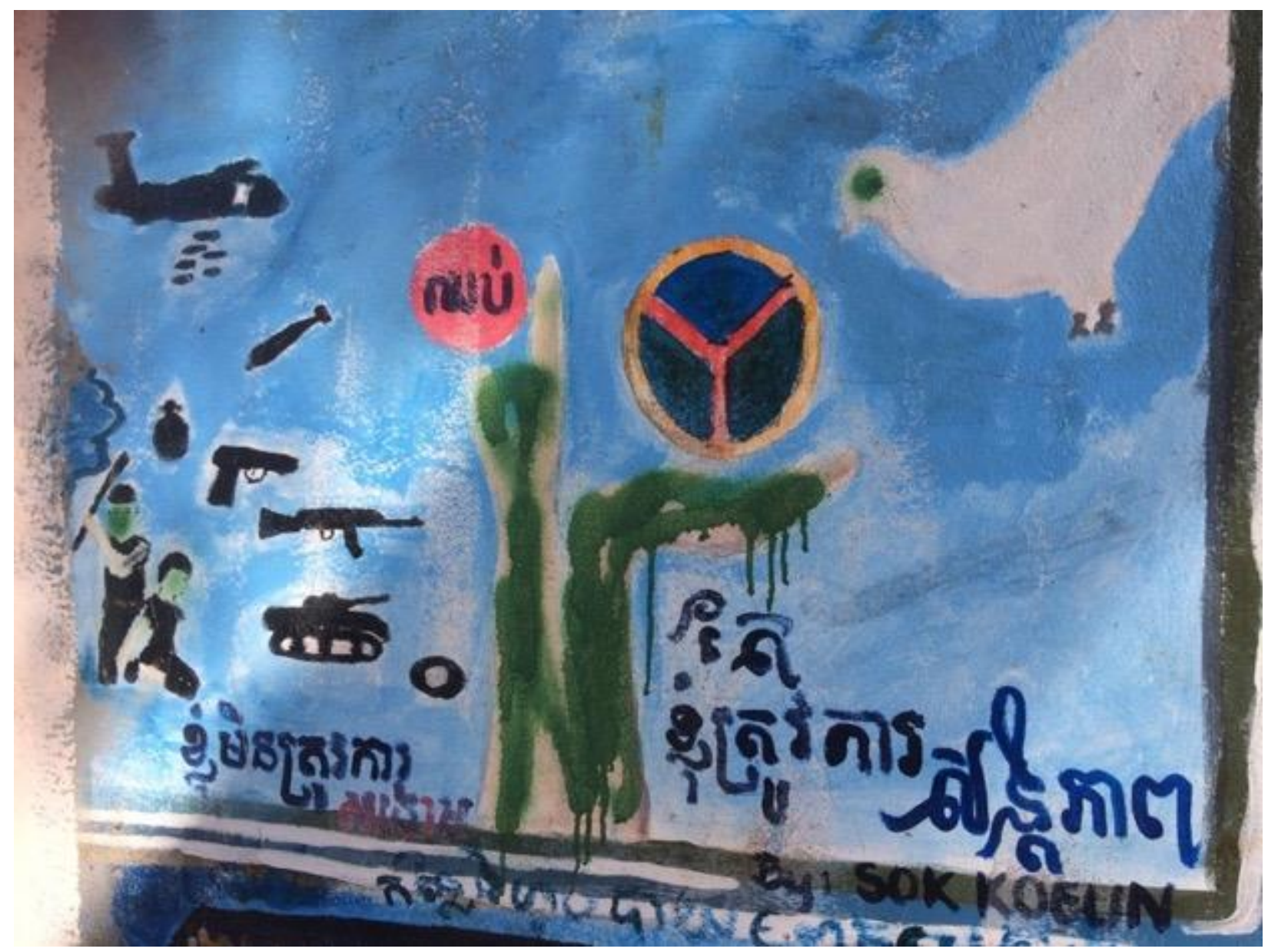

Figure 11: Painting by young people at Kraing Ta Chan

One interviewee linked education to reconciliation, that by learning about the past at these sites, young people might look for a better future...a positive change of society and...a better society. ${ }^{\prime 94}$ With regards this link between education and reconciliation, there was some suggestion that a clearer message of reconciliation could be promoted at the sites. One interviewee highlighted that the sites should not 'only just show a cruel, many cruel pictures without some message' but should have a clearer message of 'national reconciliation or healing. ${ }^{195}$

With regards to the international community, some interviewees referred to the broader international experience of genocide and emphasised

\footnotetext{
94 Interview 4, 10 January 2018.
}

${ }^{95}$ Interview 2, 8 January 2018. 
their hope that learning about the Cambodian case could contribute to genocide prevention on a global scale:

whenever they come they learn, they know and they prepare to prevent this from happening. It's very sad for human history that it happened in Germany and then it happened in Asia, it happened in Africa. It's a disaster. So ... it's good that people come and learn about it...work together to prevent such things from happening. ${ }^{96}$

As one interviewee said, the sites send an important message: 'we want to spread out to the world not to follow the Democratic Kampuchea regime related to the killing. ${ }^{97}$ This view was also reflected in the audio guides of some of the sites themselves, with the Choeung Ek audio guide urging international visitors to 'remember our past as you look into your future.'

With regards the role of the sites in ensuring non-repetition of violence, there are two particular challenges to consider. First, there is no direct link between education and non-repetition: knowing that violence was perpetrated in the past does not prevent violence being perpetrated in the future. ${ }^{98}$ As one interviewee explained, while non-repetition is a 'possibility' it is not certain, as 'when you have a political willingness to really decimate a category of the population' you may not be deterred by 'knowing that it happened before. ${ }^{\prime 99}$ However, this same interviewee did suggest that such sites can contribute positively to the aim of non-repetition:

96 Interview 1, 12 January 2018.

97 Interview 1, 9 January 2018.

98 The case of Argentina provides a useful illustration. Following a period of military dictatorship (1976-1983) during which some 10,000-30,000 people were killed, in 1983 Argentina became home to one of the world's first 'Truth Commissions' - CONADEP (National Commission on the Disappeared) - which produced a report, Nunca Más. A shorter, booklength version of the report was published and became a best-seller; it has been reprinted over 20 times and by 2007 had sold over half a million copies (Hayner, supra n 42). Yet, despite this widespread distribution of this version of the truth commission's report, Lessa has found that in Argentina, past practices are 'reproduced', specifically with regards the continuation (albeit to a lesser extent) of human rights violations which were common under the military dictatorship of 1976-1983. These include torture, disappearance and the use of excessive force by state forces (Lessa, F. (2011). 'Beyond Transitional Justice: Exploring Continuities in Human Rights Abuses in Argentina between 1976 and 2010,' Journal of Human Rights Practice, 3, 1: 25-48).

${ }^{99}$ Interview 3, 10 January 2018. 
the fact that these kind of things exist, it favours a global consciousness of the issue and creates some kind of global understanding about it,

and this can create an environment that is 'less vulnerable' to this sort of violence. ${ }^{100}$ As another interviewee argued, for a society,

by coming to a more accurate and sophisticated understanding of your own history, it does change the way your politics work in the present... I would like to think a similar process will unfold in Cambodia where a nuanced sophisticated understanding of that period of Cambodia's history will drive stronger protection of rights and better policy making. So, it's important in a practical way too. ${ }^{101}$

Second, it was suggested by several interviewees that the sites could be designed in such a way as to better emphasise the message of genocide prevention. One suggestion was that the sites could incorporate more activities which incorporate the message of genocide prevention, encourage reflection and encourage visitors to bring this message back to their communities. ${ }^{102}$

\section{HEALING}

A further function of the sites discussed by interviewees was emotional, mental, psychological and spiritual healing. This was experienced both directly - through the use of the sites for therapies (see below), visiting and lighting of incense, and through using these sites as a space to talk about the past and indirectly, as survivors see visitors coming to the site to remember and respect the dead and some reported taking comfort from that.

With regards therapies, Tuol Sleng and sites in the provinces are used by the Transcultural Psychosocial Organisation for testimonial therapy. These therapies involve interviewing survivors at the sites, and the reading of a testimony. ${ }^{103}$ One interviewee described these sessions as valuable because

\footnotetext{
100 Interview 3, 10 January 2018.

101 Interview 3, 9 January 2018.

102 Interview 2, 8 January 2018.

103 TPO Cambodia, 'What We Do,' available at: https://tpocambodia.org/healing-andreconciliation-for-victims-of-torture-of-khmer-rouge-trauma/ Accessed: 07.03.2019; TPO
} 
'telling the story can help... release all the toxins inside and...[allow] them the opportunity to be healed. ${ }^{\prime 104}$ Another interviewee spoke of how 'telling these stories can release a lot of pain. 105

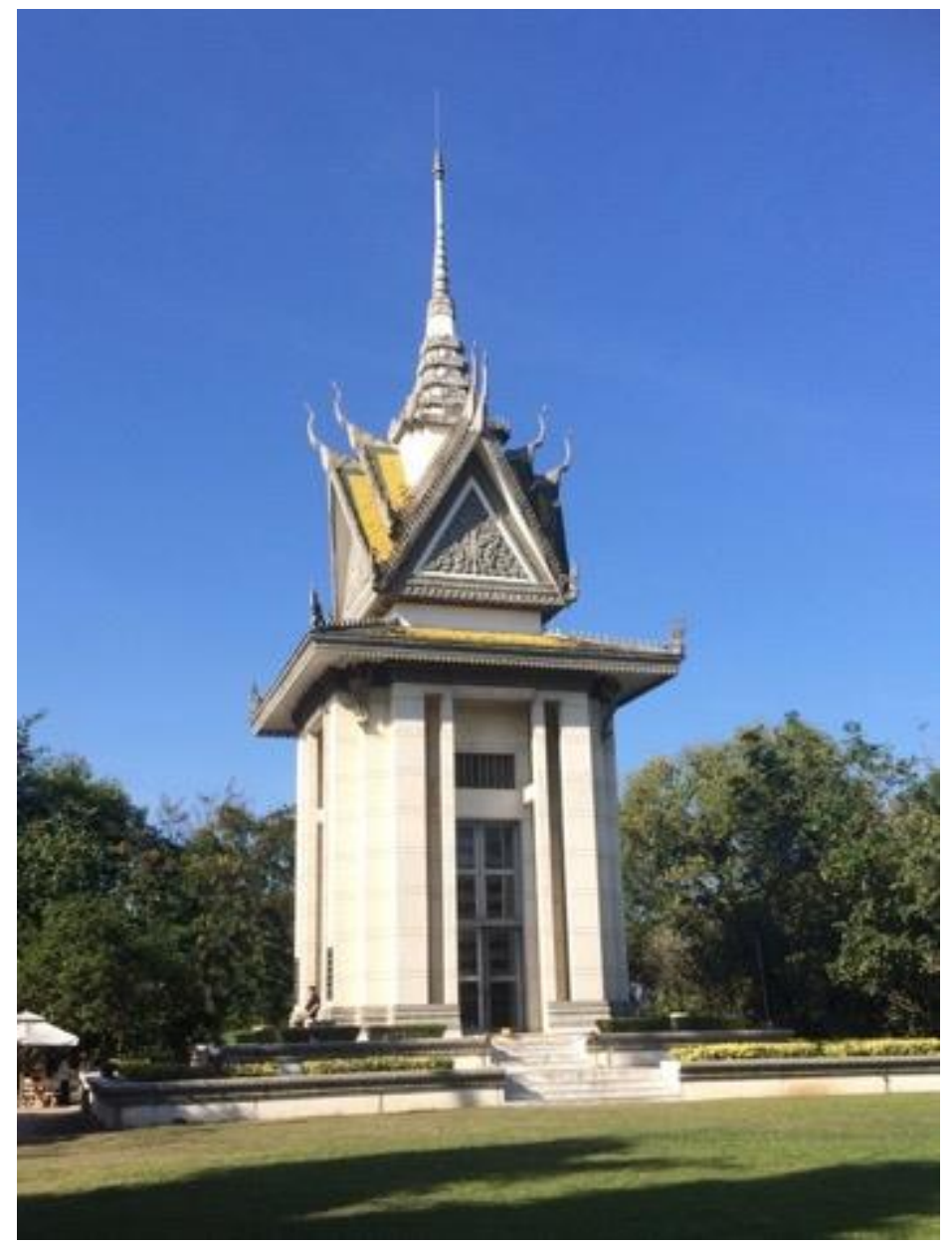

Figure 12: Choeung Ek stupa, which is used during testimonial therapy ceremonies

Across the world, cultures have their own understandings of 'how the dead should be treated,' ${ }^{106}$ and in Cambodia these understandings are strongly influenced by Buddhism as the dominant religion. Ancestors are the object of reverence, and communities often have ongoing complex

(2017), Annual Report 2017, available at: http://tpocambodia.org/wpcontent/uploads/2014/07/Final-Annual-report-2017.pdf Accessed: 07.03.2019.

104 Interview 1, 10 January 2018.

105 Interview 1, 12 January 2018.

106 Verdery, K. (1999). The Political Lives of Dead Bodies. New York: Colombia University Press. p. 42 
relationships with the dead. ${ }^{107}$ Sites such as Tuol Sleng and Choeung Ek were said to be places of spiritual healing, as the dead could be remembered and prayed for there. ${ }^{108}$ One interviewee whose parents were killed by the Khmer Rouge explained,

I want to celebrate religious ceremony and offer some food to the pagoda to bring the tribute to our parents.... I feel relief as I feel I am near them. ${ }^{109}$

Another interviewee spoke of the benefits of using the sites for conducting religious ceremonies or for meditation, as this can be calming for those with mental trauma. ${ }^{110}$ Several interviewees also spoke of encounters between former cadres and victims of the regime at Tuol Sleng and other former prison sites in the provinces. This would suggest that the sites are spaces for potential reconciliation activity. Having such space is valuable. Lederach tells us that

reconciliation-as-encounter suggests that space for the acknowledging of the past and envisioning of the future is the necessary ingredient for reframing the present. For this to happen, people must find ways to encounter themselves and their enemies, their hopes and their fears. ${ }^{111}$

Knowing that tourists visit the atrocity sites in Cambodia was also said by some to be a source of healing or comfort. One interviewee remarked: 'It is a psychological relief. When they see their dead loved ones are respected...This is a psychological relief to the victims' families'.112 A survivor of one of the sites described how:

now there are visitors coming there, it heals me spiritually to let me feel relief like someone takes each nail one by one from the wood. It makes me feel relief. ${ }^{113}$

\footnotetext{
107 Davis, E. (2016). Deathpower: Buddhism's Ritual Imagination in Cambodia. New York: Columbia University Press.

108 Interview 2, 5 January 2018.

109 Interview 2, 11 January 2018.

110 Interview 2, 12 January 2018.

111 Lederach, J.P. (1997). Building Peace: Sustainable Reconciliation in Divided Societies Washington: United States Institute of Peace Press. p.27.

112 Interview 2, 9 January 2018

113 Interview 2, 7 January 2018.
} 
While healing can be argued to be an important purpose of these sites, some caution is required. First, the sites are not readily accessible to all survivors. One interviewee highlighted that visiting Tuol Sleng and Choeung Ek is difficult for some, and that transportation or financial support might facilitate visits by more survivors to the sites. It was noted however that there are community memory sites in some localities which can be visited. ${ }^{114}$ Second, victims should not be pressured to feel healed or reconciled, as they have a right to feel angry, resentful, or even vengeful. ${ }^{115}$ Third, several interviewees mentioned that visiting the sites can be traumatising or distressing for survivors. As one interviewee described, visiting the sites can be a 'big trigger' for survivors who may 'react with [an] extreme...trauma reaction. ${ }^{\prime 16}$ However, this same interviewee said that these survivors still 'appreciate' being able to visit, and that 'even though it's painful...they still want to know about it. They see it is important.' This would suggest that while these visits are important, the appropriate professional support should be provided to survivors who may be at risk of re-traumatisation. While it is possible that Tuol Sleng, Choeung Ek, and other former security centres in the provinces may have a role in healing, we should not assume a direct or simple link. It is not the case that survivors go there and are immediately 'healed.'

\section{JUSTICE AND PRESERVATION OF EVIDENCE}

As noted in Chapter 1, Tuol Sleng and Choeung Ek and the evidence gathered there were used by the ECCC as part of the investigation and trial of Duch, ${ }^{117}$ while all four sites have featured in the ECCC's prosecution of Nuon Chea and Khieu Samphan. ${ }^{118}$ Tuol Sleng and Choeung Ek are also visited by participants in the ECCC's Outreach Programme. The sites became part of the process of ensuring the public sees justice being done as they are 'the best place to show

\footnotetext{
114 Interview 2, 8 January 2018.

115 Aldana, R. (2006). 'A Victim-Centered Reflection on Truth Commissions and Prosecutions as a Response to Mass Atrocities', Journal of Human Rights, 5, 1: 107-126; Hamber, B. and Wilson, R.A. (2002). 'Symbolic Closure Through Memory Reparation and Revenge in PostConflict Societies', Journal of Human Rights, 1, 1: 35-53; Mendeloff, D. (2009). 'Trauma and Vengeance: Assessing the Psychological and Emotional Effects of Post-Conflict Justice', Human Rights Quarterly, 33, 3: 592-623.

116 Interview 2, 10 January 2018.

117 Case 001, Appeal Judgement, 001/18-07-2007/ECCC/SC, 3 February 2012.

118 Case 002/02, Summary of the Judgment, 002/19-09-2007/ECCC/TC, 16 November 2018.
} 
the public about the crime committed during the Khmer Rouge regime ${ }^{119}$ and bringing the public to the site helps to make them aware of 'the meaningful process of justice. ${ }^{120}$

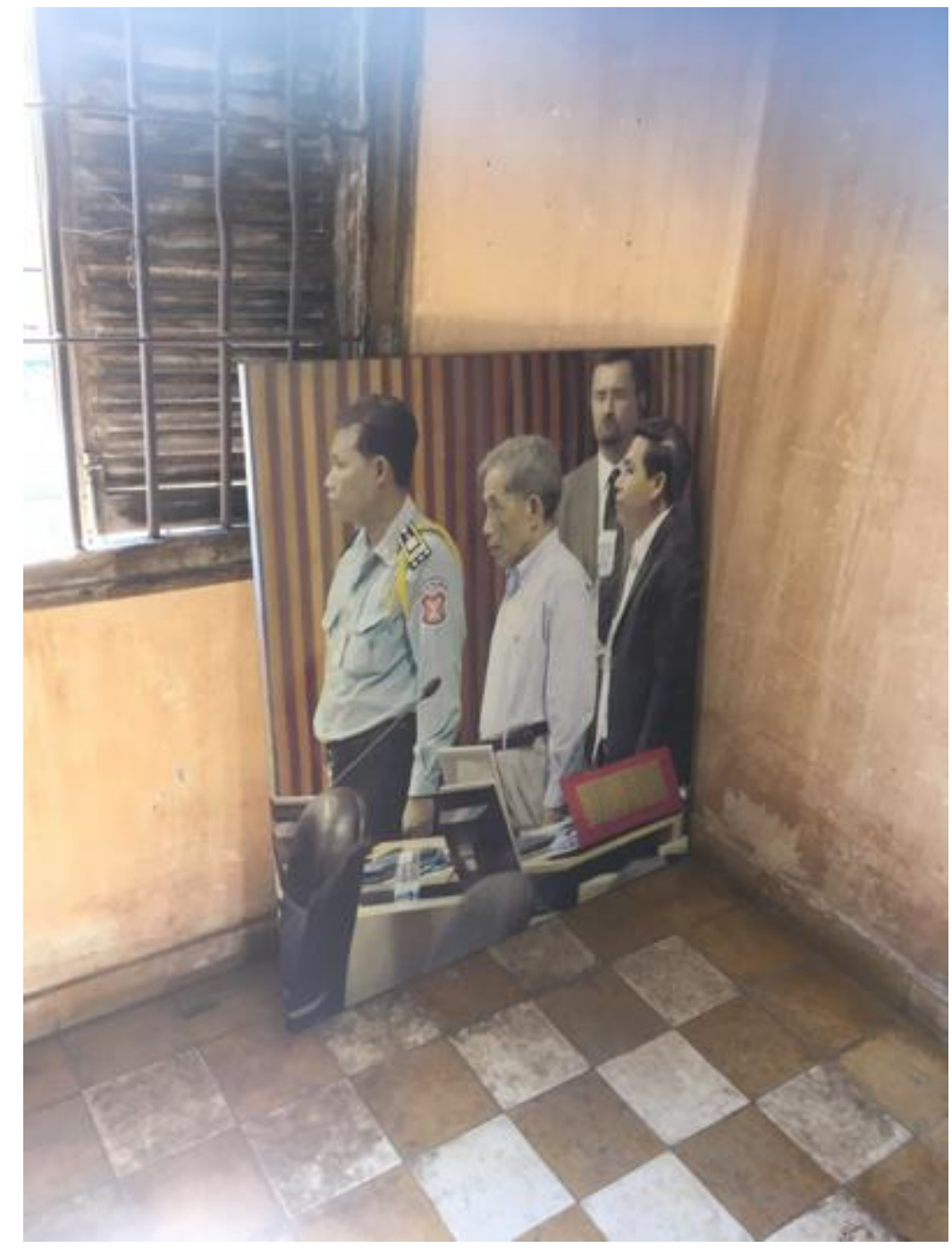

Figure 13: Picture of Duch on trial, on display in Tuol Sleng Museum of Genocide

Key to this justice function is that the sites are places where the evidence of past violence has been preserved. Various physical remains relating to the Khmer Rouge period have been preserved at the sites, ranging from buildings and structures, to human remains, to the tools and weapons

119 Interview 1, 11 January 2018.

120 Interview 1, 8 January 2018. 
used for torture, the clothing of victims, and written documents and photographs. Tuol Sleng and Choeung Ek were preserved as 'evidential places' following the fall of the Khmer Rouge regime. ${ }^{121}$ For one interviewee, this remains a key purpose of the sites:

First is preserve all evidences of what happened ... That is our objective...We preserve it to allow the people around the world to witness, and know the historical evidences of what happened in Khmer Rouge regime... we continue [to] preserve it as an evidence for the world. 122

As one interviewee described, 'when there are facts, it's important to preserve, not to deny. ${ }^{123}$ These 'crime sites, ${ }^{124}$ and the items found there, have been used as evidence in trials at the ECCC, and as proof of what happened in Cambodia by historians, NGOs such as UNESCO and DC-Cam, and others. As one historian interviewed by the project team remarked:

it's very important to preserve the documentation that was left behind...in Tuol Sleng... this museum is dedicated, among other things, to doing that. It's also the building where all this happened, it's very important to preserve that. ${ }^{125}$

Such work continues. For example, as part of UNESCO's 'Memory of the World' programme, some 400,00 documents recovered from Tuol Sleng will be digitised. ${ }^{126}$ One interviewee spoke of the value of humanising the genocide by preserving clothing: 'the clothing is kind of powerful. The personal touches on all of it.... think preserving it was a good idea'.127 At Kraing Ta Chan, where much of the former prison had been destroyed, the more recent

\footnotetext{
${ }^{121}$ Interview 1, 9 January 2018.

122 Interview 2, 9 January 2018.

123 Interview 3, 10 January 2018.

124 Interview 1, 5 January 2018; Interview 1, 7 January 2018.

125 Interview 1, 22 November 2017.

126 UNESCO, 'Speech: Launch of Digitization of Toul Sleng Museum's Document, open remarks by Ms. Anne Lemaistre, UNESCO Representative in Cambodia' http://www.unesco.org/new/en/phnompenh/about-this-office/singleview/news/speech launch of digitization of toul sleng museums docu/ (accessed 09/01/18)

127 Interview 4, 9 January 2018.
} 
move to develop a museum was explained as being in part 'for the installation of the historical evidences. ${ }^{\prime 28}$

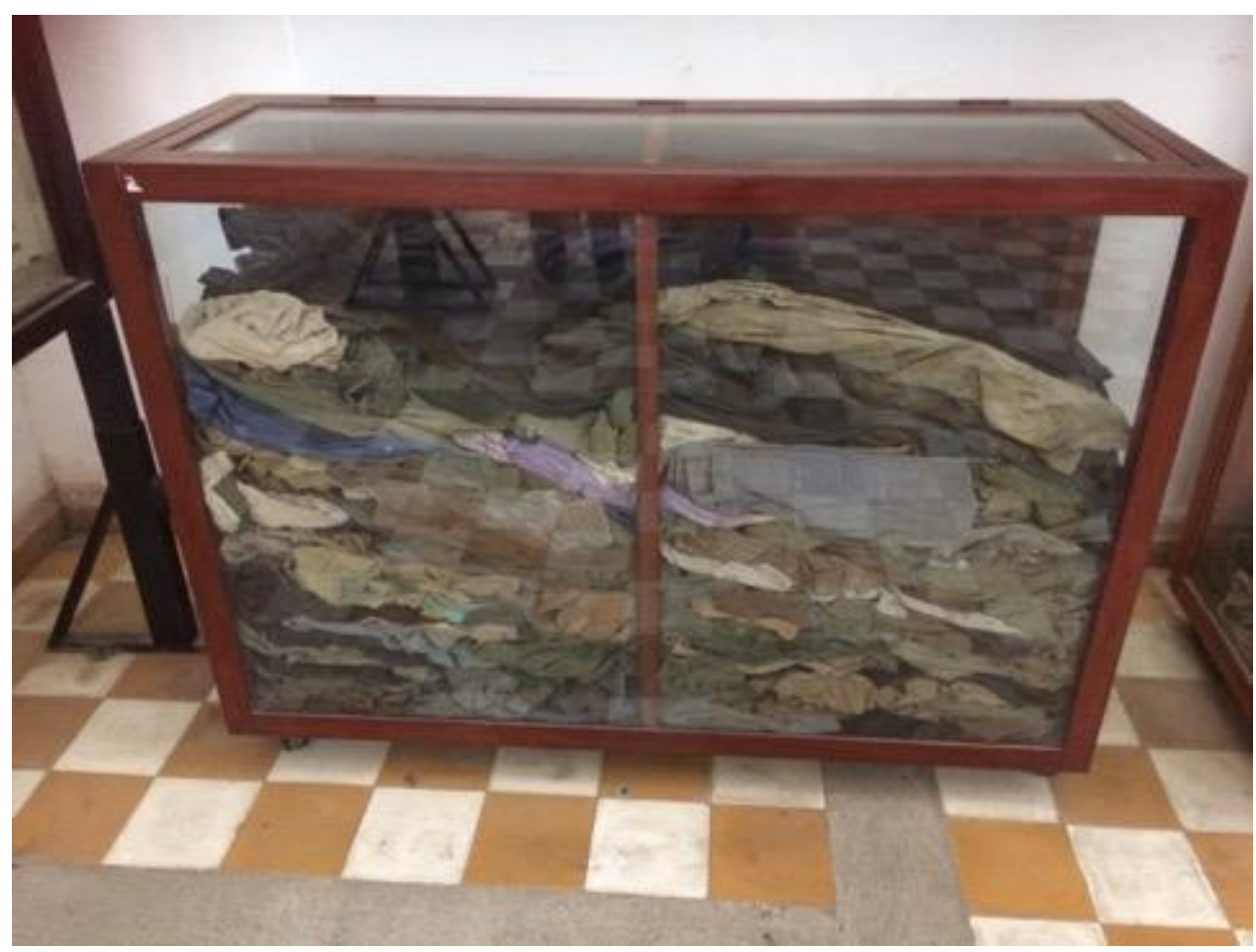

Figure 14: Preserved clothing at Tuol Sleng Museum of Genocide

For one survivor we spoke to, it is imperative that this legacy is preserved - particularly after survivors have passed away:

we all as the survivors going through the $K R$ regime are obliged to preserve the history as the legacy for the young Cambodians and the world to learn about the regime. ${ }^{129}$

A number of interviewees expressed concern that without physical evidence of what took place, the accounts of Cambodians would not be believed, or that history would be forgotten: 'If there is no physical evidence, it won't be believed.' 130 On a related note, some concern was raised about the preservation of former security centres - particularly in the provinces. As one

128 Interview 2, 13 January 2018.

129 Interview 2, 12 January 2018.

130 Interview 1, 15 January 2018. 
interviewee remarked, 'a lot of crime sites are not being preserved and they have been destroyed. ${ }^{131}$ Another mentioned:

in the provinces, in the remote areas, a lot of sites...ignored and destroyed by nature. So, if you do not...mobilise communities to understand that and keep it, it will be lost. ${ }^{132}$

Another highlighted the risk to sites of mass graves:

it's good that they make some preservation but due to climate, due to rain, I think this kind of original grave disappears. I don't know what way that can be preserved. ${ }^{133}$

\section{REMEMBRANCE AND HONOURING THE PAST}

One interviewee described the sites as 'the remembering place' where memory is conserved. ${ }^{134}$ Memorialising victims and honouring the past were highlighted by many interviewees as important purposes of the sites.

Internationally, several interviewees described, sites associated with past atrocities are preserved as places to honour the dead. Tuol Sleng and Choeung Ek share this purpose:

I went to a similar institution in France recently... the only concentration camp in France which still remains, all of the other ones were destroyed ... now it's a major archive and wonderful museum for the memory of the 2,500 deportees ... that is another example of a structure that has been luckily preserved. And I think if this museum hadn't been set up in Tuol Sleng, that building might have been destroyed or gone back to being a high school as it was before. Who knows what would have happened but the memory of what happened to all those 16,000 murdered victims is somehow being honoured. ${ }^{135}$

\footnotetext{
${ }^{131}$ Interview 1, 5 January 2018.

132 Interview 4, 10 January 2018.

133 Interview 1, 10 January 2018.

134 Interview 1, 11 January 2018.

135 Interview 1, 22 November 2017.
} 
As one interviewee described, one of the ideas behind preserving sites associated with the genocide is that they are 'central places' to show

respect to the people who died during the Khmer Rouge regime... we [do] not go to Tuol Sleng or Choeung Ek for pleasant... we remember people who died and we pay respects and we think that their soul is in peace. ${ }^{136}$

Visitors to the sites, we were told, 'feel pity' for the victims and 'recall the sadness. ${ }^{137}$ The gathering of human remains and their displaying in stupas at the sites was described as a way of showing the dead 'dignity, 138 as following the fall of the Khmer Rouge, remains were scattered across the countryside.

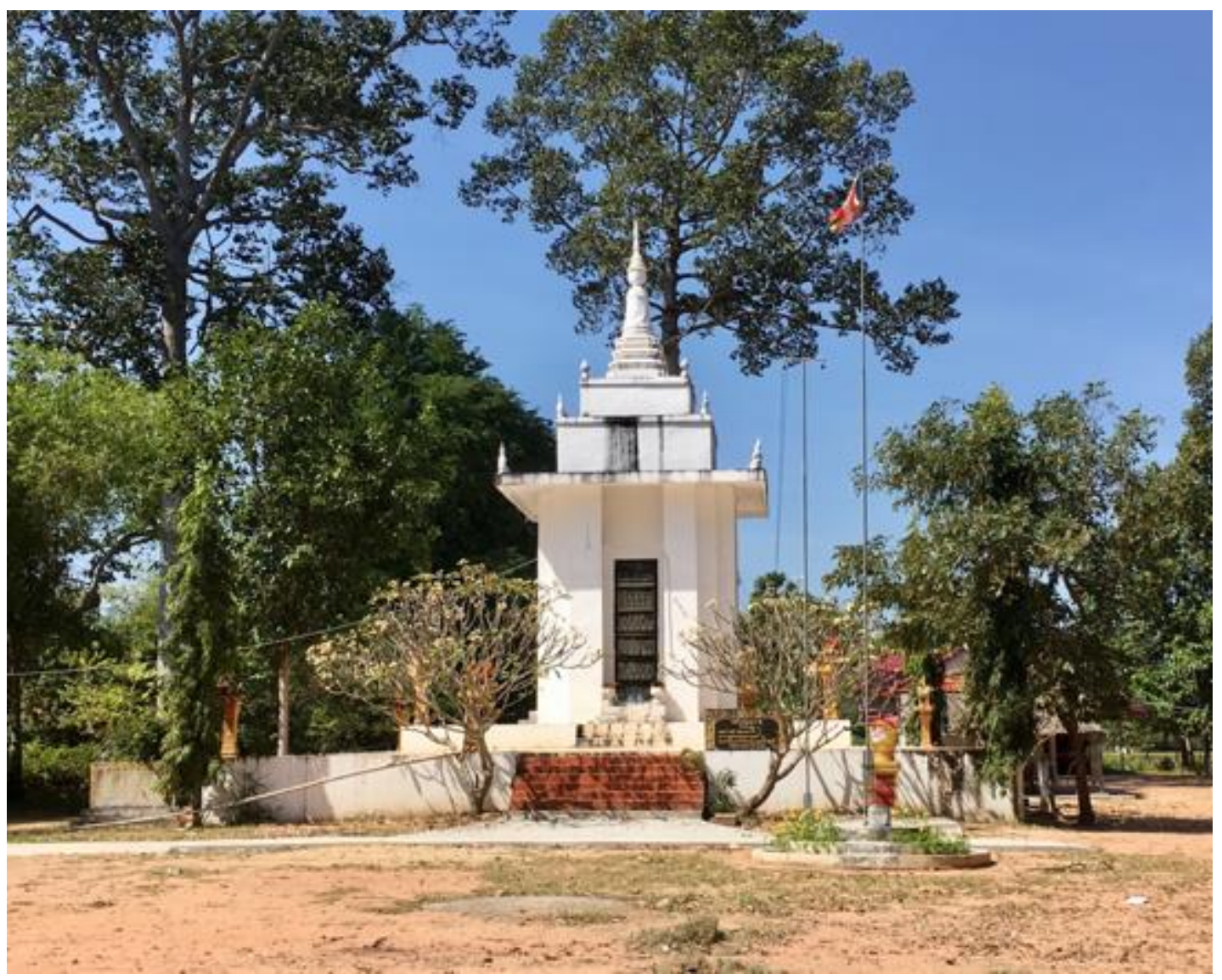

Figure 15: Stupa at Kraing Ta Chan

The sites are places where the memory of victims can be honoured by praying, the lighting of incense, and respectful contemplation. The sites are

136 Interview1, 5 January 2018.

137 Interview 1, 11 January 2018.

138 Interview 2, 13 January 2018. 
used for remembrance events, such as the May 20 Remembrance Day of the victims. Youth for Peace have worked with communities in the provinces, including at the site of Kraing Ta Chan, on community memory initiatives which transform former sites of mass killing into community learning centres. These projects involved the local communities so that they can participate in telling their own history at the memory sites. ${ }^{139}$ With regards former prison sites and labour camps in the provinces, one interviewee was concerned that if there were no museums or memorials to mark the sites, that they might be lost: 'It is to have the remembrance of the history. If not doing so, all will be gone. ${ }^{140}$ As will be examined in Chapter 3, decisions over who should be remembered at these sites complicate the role of these sites as places of memorialisation.

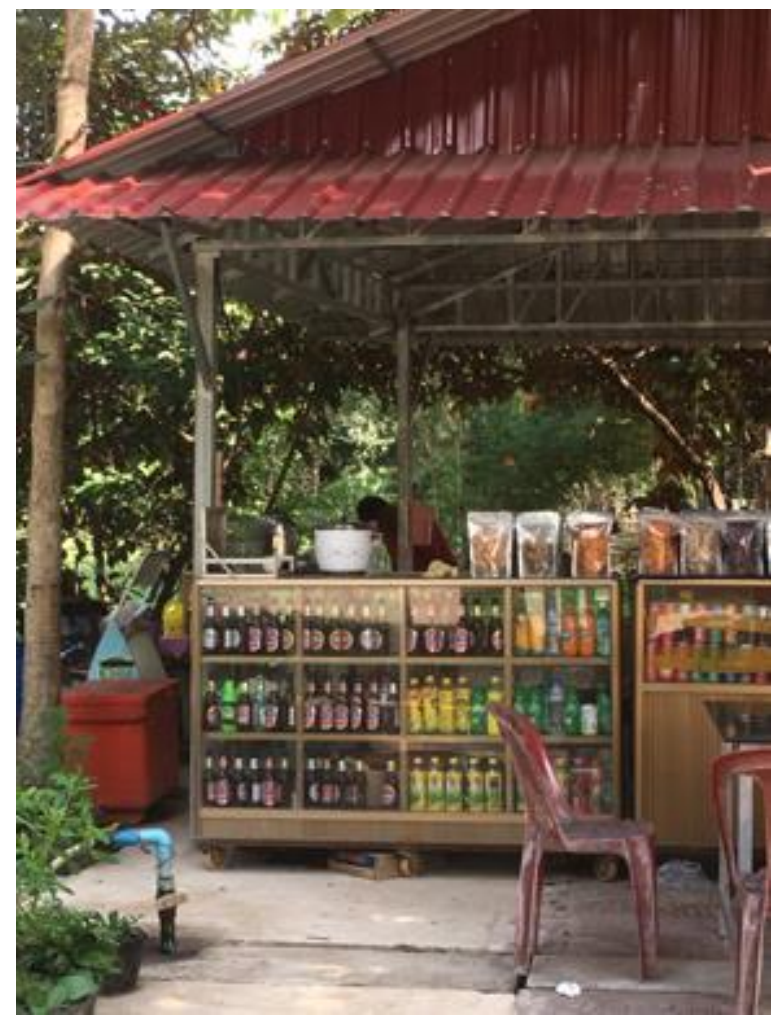

Figure 16: Shop at Choeung Ek Killing Fields

139 Khet, L. (2011). Initiating a Way to Address Legacy of Memory in Cambodia. Youth for Peace; The Peace Institute of Cambodia: Action Research Paper; Youth for Peace. (2011). 10 Years of Peace Activism. Youth for Peace; The Peace Institute of Cambodia: Action Research Paper.

140 Interview 1, 15 January 2018. 
It should be noted that there is a risk that the development of these sites as places for tourists to visit might clash with their purpose as places where the past is honoured. One interviewee emphasised how important it is that visitors show respect:

respect to the spirit of the victim... that place is not the happy place or the supermarket place but this is the place that we need to respect. To keep silent, quiet and respect the rules there because it's not a happy place because there... it means a sad place. ${ }^{141}$

Interviewees suggested that while the selling of books relating to the Khmer Rouge period was important, and that water should be available for visitors to buy, other items should not be sold at the sites as these places are not markets, rather they are places of commemoration where respect should be shown for victims. ${ }^{142}$ One survivor interviewed suggested that graphic images of violence might detract from the peaceful, reflective atmosphere of the sites. ${ }^{143}$

\section{CONCLUSION}

In this Chapter, the interviews we conducted during two weeks of fieldwork in Cambodia in January 2018 were used as a basis for exploring the range of ways in which sites of atrocity have been re-envisaged to serve valuable functions in present-day Cambodia. The sites are of use to survivors of the Khmer Rouge regime, to wider Cambodian society, and to international visitors. Tuol Sleng, Choeung Ek, and sites in the provinces have come to serve as places of: acknowledgement and truth; education and guarantees of non-repetition; healing; justice and the preservation of evidence; and remembrance and honouring the past. What these various functions indicate is that sites associated with past mass violence can be focal points for education, truth, memorialisation and honouring the past, and perhaps also healing and reconciliation.

A number of challenges to these various purposes have been highlighted. First, there are issues of access. In order for these sites to be of

\footnotetext{
${ }^{141}$ Interview 1, 11 January 2018.

142 Interview 1, 6 January 2018; Interview 2, 7 January 2018; Interview 2, 12 January 2018;

Interview 3, 16 January 2018.

143 Interview 3, 16 January 2018.
} 
use to those most impacted by past violence, resources may need to be made available to facilitate this. Second, these different functions at times compete with one another. For example, the visiting of large numbers of tourists and the display of violent imagery and implements might impact upon the role of these sites as places for peaceful and respectful contemplation of the dead. The addition of the White Lotus Room at Tuol Sleng as a quiet space is a welcome addition in this respect. Third, much of the value of these sites comes from their being the places where violence actually took place. As such it is imperative that the sites are preserved - and that this is done so in a way that maintains authenticity. One way to address these various issues might be to include victims and survivors in decision-making around the design and development of sites of past atrocity. 
In this chapter we consider the relationship between sites of atrocity and how the experience of victimhood in Cambodia under the Khmer Rouge is represented. Drawing on our fieldwork and site visits, four key themes are discussed: the importance victims and survivors placed on being able to tell their story; the need to represent victims' voices as fully as possible; the importance of reflecting the complexity of the past; and finally, the question of who benefits from the preservation of sites of atrocity and their role as tourist destinations.

These themes are not unique to Cambodia's sites of dark tourism. In many other post-conflict jurisdictions, questions are increasingly being raised as to whether more could be done to represent and promote the voice and agency of victims and survivors and how to deal with competition and conflict over the meaning of victimhood post-conflict. ${ }^{144}$ Engaging with these issues in the Cambodian context has the potential to assist in the promotion of a more 'victim centred' approach to dealing with the legacy of the Khmer Rouge and ensuring that former sites of atrocity are used and developed in a sensitive and respectful manner.

\section{VICTIMHOOD AND BEARING WITNESS TO THE PAST}

One of the clearest themes which emerged across many of the interviews conducted by the research team with victims and survivors was the importance of being able to tell the 'story' of life and victimisation under the Khmer Rouge regime. Indeed, a number of survivors described themselves as a 'living document' of that period of time. Within this theme of 'bearing witness to the past', we have identified three areas of importance - bearing witness

\footnotetext{
144 See for example: Fletcher, L. and Weinstein, H. (2017). 'Transitional justice and the 'plight' of victimhood'. In: Lawther, C., Moffett, L. and Jacobs, D. (eds). Research Handbook on Transitional Justice. Cheltenham: Edward Elgar. 244-266; McEvoy, K. and McConnachie, K. (2013). 'Victims and transitional justice: voice, agency and blame', Social and Legal Studies, 22, 4: 489-513; Druliolle, V. and Brett, R. (2018). The Politics of Victimhood in Post-Conflict Societies: Comparative and Analytical Perspectives. Basingstoke: Palgrave Macmillan.
} 
to the past within and beyond Cambodia; the therapeutic value of sharing details of the past; and the preservation of memory. Each is discussed in turn below.

First, a number of our interviewees made an explicit connection between their ability to participate in this research project to the articulation of their voice within and beyond Cambodia -

I would like to tell you all that I am happy for being interviewed. I am excited and I hope that my life story document, my voice from Tuol Sleng could be widely spread to the world. ${ }^{145}$

Another research participant closely echoed this theme, with a particular emphasis on recognizing the horror of detention and imprisonment at Tuol Sleng:

I am committed to coming to participate in this meeting because I want to share with you of the reality happened in here. What was this place before? What is displayed here? All display here are real not created. All stories here are true. I want to show this to you to know and for the young generation to learn as well the international visitors to know that all stories here are true not fake. ${ }^{146}$

The following quote further develops this idea. It speaks to the importance of knowledge transfer, awareness raising and the potential impact of physically visiting sites associated with atrocity:

...knowing is not enough. ... It has to be constantly on people's minds, you can't just say 'oh yes, we know the Pol Pot regime is terrible'. There has to be a larger number of people that know it, or it has to be known at some greater level of public awareness or it has to become a critical mass that becomes a political impact and that's where I think maybe tourism can help. ${ }^{147}$

Second, for other survivors and as discussed in Chapter 2, being able to share their experiences with visitors had a therapeutic value. This point was captured by the following interviewee:

\footnotetext{
145 Interview 1, 6 January 2018.

146 Interview 1, 7 January 2018.

147 Interview, 10 January 2018.
} 
It is great that we as a survivor talk about what we went through.... Talking to the visitors gives them an opportunity to listen, hear and know reliable and clear information through a living document. The more I talk to the visitors, the more I feel particular relief because I share my story to a lot of people from different countries around the world to listen to it. ${ }^{148}$

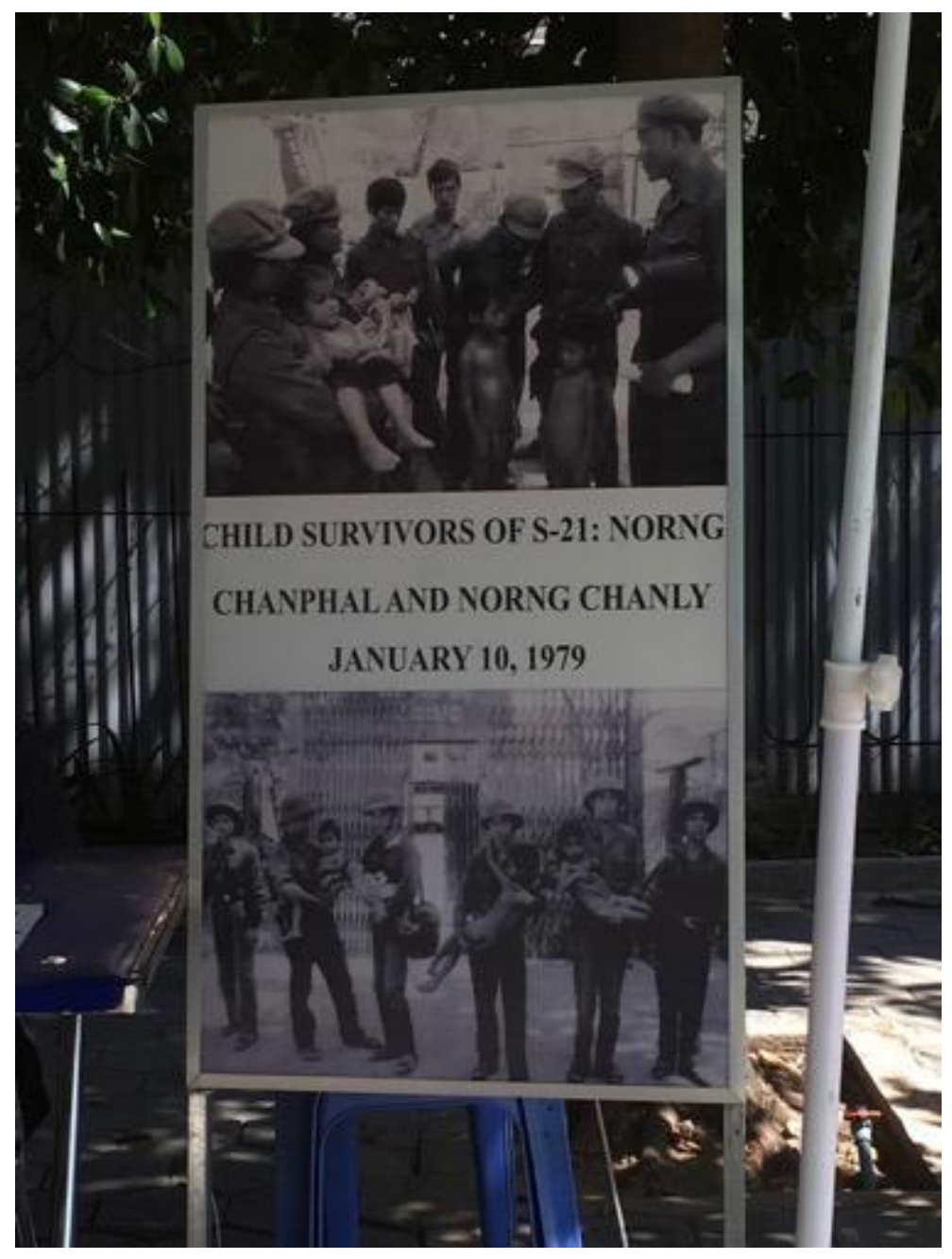

Figure 17: Stall advertising the sale of a survivor's book at Tuol Sleng Museum of Genocide

Thirdly, and as noted in Chapter 2, a number of interviewees linked the tourist facing role of the sites with the preservation of memory. Indeed, the importance of securing first-hand personal memory appeared to weigh heavily on a number of participants. In other cases, and as is evidenced in other post conflict societies, the importance of preserving the physical

148 Interview 1, 7 January 2018. 
structures of the past to 'keep the history' and to 'respect and conserve the memory' was highlighted. ${ }^{149}$ As the following quotes demonstrate, for two interviewees, the sites were also considered an important place from which to reflect on and honour the past with a forward looking lens.

And I think if this museum hadn't been set up in Tuol Sleng, that building might have been destroyed or gone back to being a high school as it was before. Who knows what would have happened but the memory of what happened to all those 16,000 murdered victims is somehow being honoured. ${ }^{150}$

What I want to tell is just to make the sites into action, you know, it's very important not just to go there and visit, you know, go back like a resort. No, we don't want that. Go there, have reflection, come back, bring the message to the community and healing, not bring the sadness and nightmare. We don't want that. ${ }^{151}$

\section{VICTIMHOOD AND REPRESENTING VICTIMS' VOICES}

Closely aligned to the idea of bearing witness to the past is the importance of representing victims' voices as fully as possible. In many ways this is not surprising - it is, for example, well established that using one's voice can have a therapeutic value and plays a key role in broadening out our understanding of past violence. ${ }^{152}$ However, the importance placed by our interviewees on hearing and representing victims' voices attests to the fact that the representation of a plurality of voices has not yet been fully realized in relation to the sites. A number of overlapping areas were identified amongst interviewees, including the relationship between telling 'the story' and acknowledgment and empowerment and the importance of including victims and survivors in the development of the sites. Each is explored in turn below.

In the context of Tuol Sleng, a small number of interviewees alluded to contests over the 'true' story of Tuol Sleng and who 'owns' that narrative. However, interviewees were unanimous in the critique that while, 'every victim

\footnotetext{
149 Interview 1, 7 January 2018.

150 Interview 1, 8 January 2018.

${ }^{151}$ Interview 2, 8 January 2018.

152 See for example: Laub, D. (1992). 'Bearing Witness, or the Vicissitudes of Listening'. In:

Feldman, S. and Laub, D. (eds). Testimony: Crises of Witnessing in Literature, Psychoanalysis, and History. Abingdon: Taylor and Francis. 57-74. Govier, T. (2015). Victims and Victimhood. Peterborough, Canada: Broadview Press.
} 
has a story to tell and we need places for them to tell it ${ }^{153}$, there are many thousands of survivors who have not been heard:

...many, many victims have not been heard you know, especially their voice, only I think hundreds, more than a few hundreds who are involved in the healing process as victim civil parties, but millions, thousands of other victims could not be recognized, their voice...it's very important to listen to the story of the survivors. ${ }^{154}$

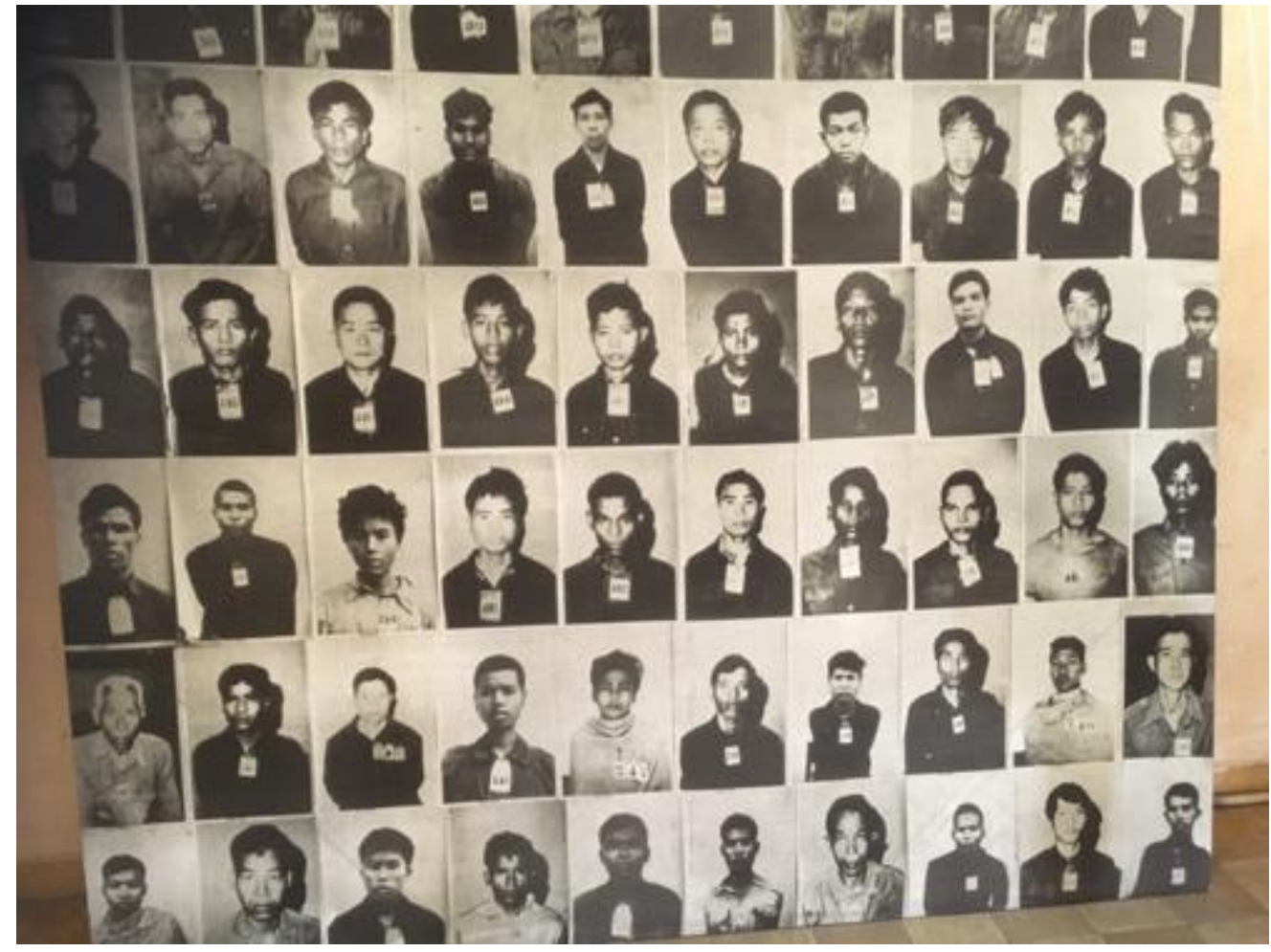

Figure 18: Display of victim photos in Tuol Sleng Museum of Genocide

For one interviewee, this extended to encouraging victims to 'hear' the story of the physical artefacts held in places like the Tuol Sleng Museum:

I always ask them please talk to the photo and some of them they seem not understand, please talk to the photo or talk to the prison. I mean that when you visit there you need to learn something about the photo, to ask them to look at what happened during that time. It's like some people visit Angkor Wat they say that 'oh, it's just only the stone' but no, you need to ask the stone what happened. So, I encourage them to learn something when they visit. ${ }^{155}$

153 Interview 1, 6 January 2018.

154 Interview 4, 10 January 2018.

155 Interview 4, 10 January 2018. 
In keeping with recognition of the complexity of victimhood (as discussed below), interviewees considered it important that a plurality of voices be heard - 'it was not only me but tens of thousands of prisoners detained there' including those of former perpetrators. ${ }^{156}$

Interviewees were also keen to emphasise, that where survivors are on site and willing to talk to visitors, such interaction should be facilitated by tour guides. This was often allied to a critique of the use of audio guides which some interviewees felt discouraged visitors from fully engaging with the sites and with opportunities for engagement and dialogue with survivors. From the perspective of some survivors, this was a matter of dignity and part of their desire to exercise their voice and agency out of respect for those who were denied voice and agency and who did not survive the Khmer Rouge regime.

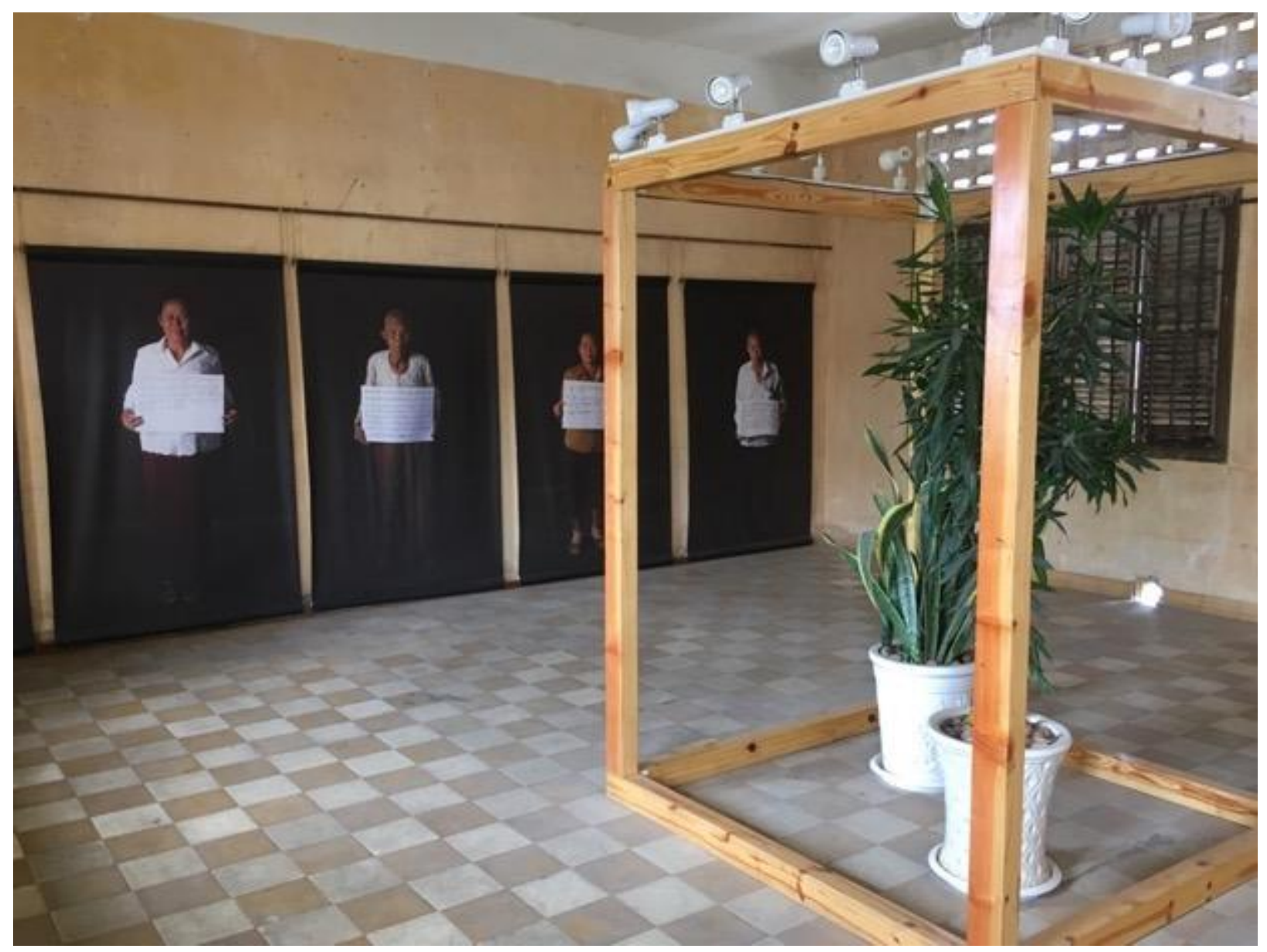

Figure 19: Exhibition of Civil Parties at Tuol Sleng Museum of Genocide

One interesting finding was the suggestion that those victims who are civil parties at the ECCC and have testified before the court, have, on

156 Interview 2, 7 January 2018. 
subsequent occasions, found it easier to recount their experience. This finding speaks both to feelings of acknowledgement and empowerment that have come as a result of being able to tell their story before an appropriate audience - '...it is important to empower them enough and to make sure that it's okay and the story is acknowledged and we believe the survivor', ${ }^{157}$ but also to the importance of giving survivors the time and space in which to find their voice. However, potentially more challenging are levels of literacy, particularly amongst survivors in more rural areas. As one interviewee pointed out, and drawing on his own family experience, the ability of survivors to find out about and engage in storytelling initiatives is hindered by the practical reality of often needing to be able to read and write. This finding raises important considerations for local and international non-governmental organisations working in Cambodia.

A further theme that was identified by interviewees was the ability of survivors to contribute to the development of former sites of atrocity, particularly those with an outward facing focus. For example, as one interviewee argued, this is about

...the involvement and the ownership of the victims and the communities around mass killing sites, that's why it's very important because they participate in a creation of people's history. It's not the history of the victims, this is the history of the people. ${ }^{158}$

A number of our interviewees however expressed dissatisfaction and disappointment at the lack of opportunities afforded to survivors when developments and displays in sites have been created. While such critiques do point to competition over who has the 'true voice' (of Tuol Sleng in this instance), they are also reflective of the importance survivors have attached to being able to tell their story, retain ownership of their experience and see that reality reflected in the physical development of these sites. ${ }^{159}$ As one interviewee argued, '... we need to have the participation from the victim also because this is their story'. 160 This point was reinforced by another interviewee, who also expressed concern regarding the long term authenticity of the sites:

They at least need to ask the victims and survivors who witnessed all things that happened during their arrest and imprisonment in here. What I witnessed is gradually gone. ${ }^{161}$

\footnotetext{
157 Interview 2, 10 January 2018.

158 Interview 1, 10 January 2018.

159 Interview 1, 6 January 2018.

160 Interview, 5 January 2018.

${ }^{161}$ Interview 2, 7 January 2018.
} 
There are of course a number of examples where survivors have been directly consulted about the development of community-orientated projects. During our fieldwork we were fortunate to speak with a community development worker who outlined their own participatory consultation approach to developing local storytelling and memorialisation initiatives:

We start with storytelling, survivor especially, they tell what their story is from the Khmer Rouge. After that, we invite one or two participants to talk about the story of the site which they will understand. ... we come again for the second consultation and we asked to validate some of the ideas that they come up with and talk about plans, what they want to do at that site. ${ }^{162}$

Such direct engagement in 'bottom up' approaches to conflict transformation was recognized in Cambodia, as it has been internationally, as promoting agency and ownership of conflict amongst victims and ex-combatants and contributing to the empowerment and restoration of damaged communities. ${ }^{163}$

\section{VICTIMHOOD AND REPRESENTING A COMPLEX PAST}

Over the last decade, the complexity of victimhood has been increasingly recognised by researchers and practitioners. ${ }^{164}$ The research team responsible for this project are all based in Northern Ireland where, following 30 years of conflict, the question of who is a 'victim' or 'perpetrator' remains highly contested. ${ }^{165}$ This is often due to the association between victimhood and concepts of innocence and blamelessness. ${ }^{166}$ Our research in Cambodia did not reveal the same divisions regarding who can be defined as a victim or perpetrator. Rather, there was much more recognition of the fluidity of victimhood and the fact that many Khmer Rouge cadres were victims of the Khmer Rouge too. ${ }^{167}$ The following short statements illustrate this point: 'for

162 Interview 4, 10 January 2018.

163 McEvoy, K. and McGregor, L. (2008). Transitional Justice from Below. Grassroots Activism and the Struggle for Change. London: Hart.

164 See for example, Bouris, E. (2007). Complex Political Victims. Connecticut: Kumarian.

165 See for example, Lawther, C. (2014). 'The Construction and Politicisation of Victimhood'.

In: Lynch, O. and Argomaniz, J. (eds). Victims of Terrorism: A Comparative and Interdisciplinary Study. London: Routledge. 10-30.

166 See for example, Lawther, C. (2014). Truth, Denial and Transition. Northern Ireland and the Contested Past. Abingdon: Routledge.

167 A number of interviewees did however allude to the inclusion of cadres names on the stupa at Tuol Sleng as having been problematic. This is despite the fact that over $80 \%$ of victims at Tuol Sleng were Khmer Rouge cadres. 
me and for the court, those who died during the DK regime, they are victim of the Khmer Rouge regime'; 168 'Well, one way or another, everyone is a victim ${ }^{\prime}{ }^{169}$ Accordingly, it was considered important that the stories of former cadres were told at sites such as Tuol Sleng. In the words of one survivor: '...because they did nothing wrong and were killed'. ${ }^{170}$

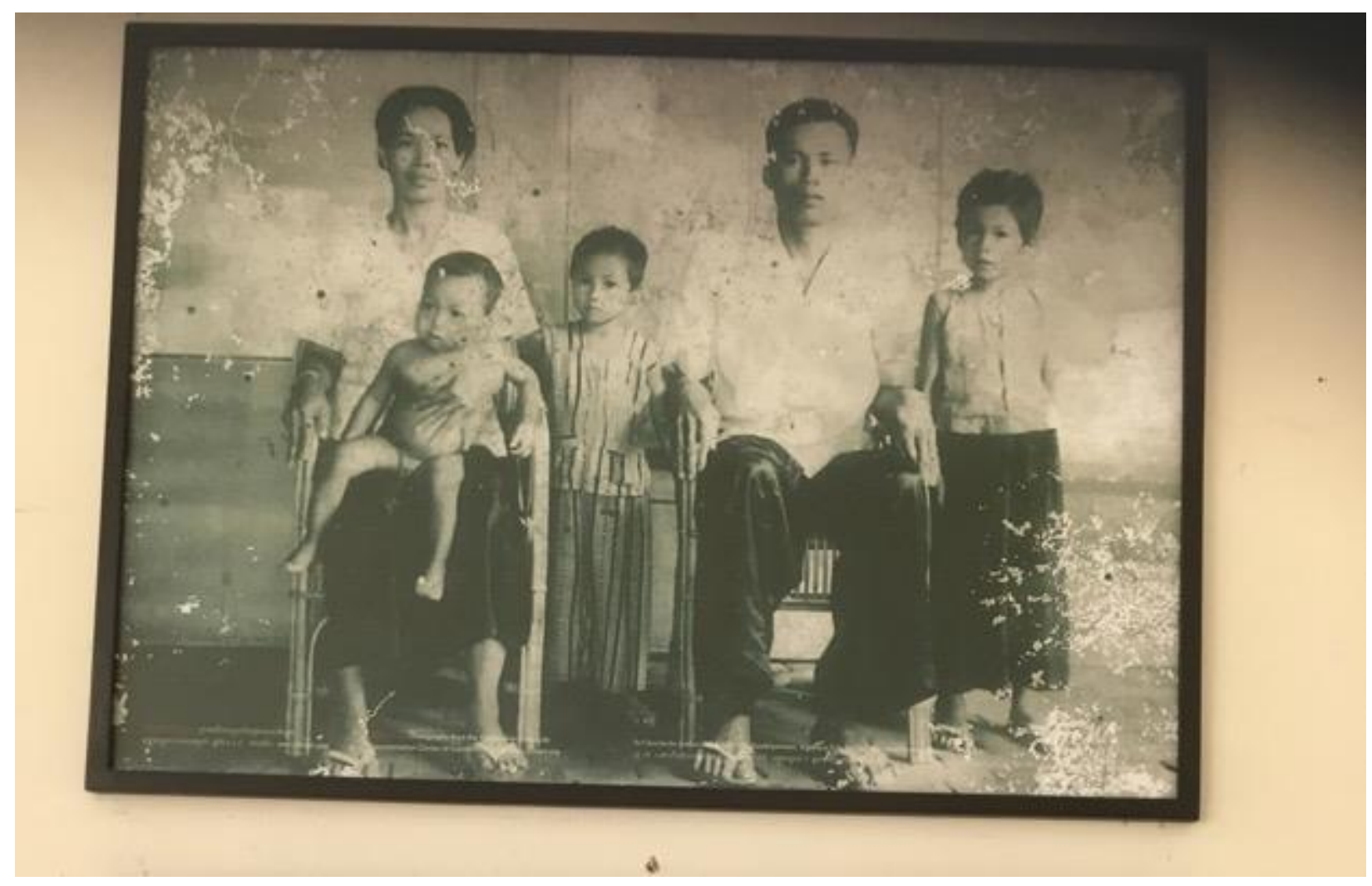

Figure 20: Photo of Khmer Rouge military and family in Tuol Sleng Museum of Genocide

That said, this recognition of the victimhood of former cadres did not extend to the senior leaders of the Khmer Rouge. This is particularly evident and encouraged in the visual displays and audio guides at Tuol Sleng and Choeung Ek, where Pol Pot and other senior leaders of the regime are repeatedly condemned. In this respect, a clear line is drawn between those 'most responsible' for the genocide and lower level cadres. Survivors and former low-ranking cadres interviewed by the research team welcomed this division of responsibility and advocated that this be made clear to visitors:

168 Interview 1, 11 January 2018.

169 Interview 1, 10 January 2018.

170 Interview 1, 6 January 2018. 
But sometimes we cannot acknowledge for example, when they say that 'oh, I am also a victim'. In the trial they said 'my whole family also killed and so on, I'm the victim' but you are the killer, a big killer so we cannot acknowledge that. We can acknowledge that your families were killed, and your family is the victim, but you are not. ${ }^{171}$

...I was not the leader. I was treated and ordered like a dog. ...I ask the foreign visitors please distinguish the bad and the good, the lower and the senior. It is not correct to mix it all up. ${ }^{172}$

Closely allied to the complexity of victimhood, are the range of harms that were experienced during the Khmer Rouge regime. On visiting sites such as Tuol Sleng, Choeung Ek or Kraing Ta Chan, the focus on violent death is immediately apparent. Given that an estimated 1.7 million members of the Cambodian population died between 1975 and 1979, this is understandable. However, it masks the range of harms that resulted in victimization and death, in particular, the experience of forced labour, starvation and sexual violence. Such selectivity inevitably determines the victimizations that we 'see' as opposed to those which we do not 'see'. ${ }^{173}$ It has also contributed to the concentration of memory on high profile security centres and killing fields such as Tuol Sleng and Choeung Ek, with the result that other sites associated with starvation, death and over-work under the Khmer Rouge such as the Kampong Chhnang airport have been side-lined in the historical narrative.

Our interviewees were not immune to this point. One interviewee was keen to stress that both the diversity of harms suffered during the Khmer Rouge period and the experience of victimization across Cambodia be recognized. Speaking on his experience at a forced labour site, he argued,

I want all stories to be included related to the Democratic Kampuchea regime. ...People living in Kampong Chhnang suffered terribly. ...the killings of the people from all over the country took place in this province.

There was not enough food, just a very limited ration. It means the transfer to work...is not the killing but the overwork leading to sickness that people died one by one. ${ }^{174}$

\footnotetext{
171 Interview 2, 8 January 2018.

172 Interview, 14 January 2018.

173 Mawby, R. and Walklate, S. (1994). Critical Victimology: International Perspectives. London: SAGE. p.19.

${ }^{174}$ Interview, 15 January 2018.
} 


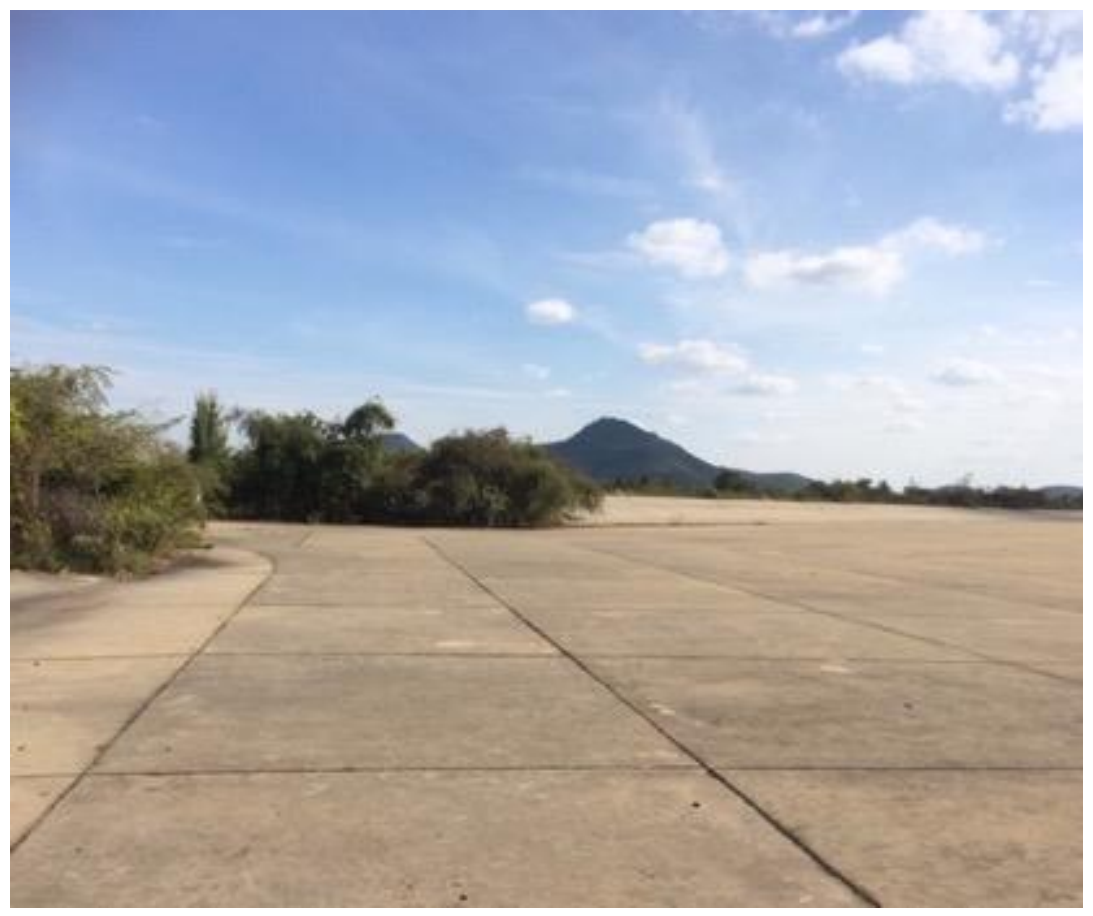

Figure 21: Kampong Chhnang Airfield, a site of forced labour during the regime

Other interviewees reflected these themes with respect to victims of forced labour and gender-based violence. Uniting each was a concern that with the promotion of some harms - violent death, and invisibility of other harms - starvation, exhaustion and sexual violence, hierarchies of harm and victimhood were being created in Cambodia. This has both created a narrow understanding of the experience of life under the Khmer Rouge and has left some survivors feeling that their history and their voices have not been recognized. One interviewee was particularly critical, arguing that in Cambodia, 'we do not have the voices of the many, but we have the voice of Tuol Sleng'. ${ }^{175}$ Being able to 'see the whole picture of the person when they suffered', 'the whole story', was considered essential to promoting dignity and an accurate memory of the past amongst victims and survivors. ${ }^{176}$ As explored in Chapter 2, recognizing the full range of harms is also key to establishing 'the full truth of what happened and why'. ${ }^{177}$

\footnotetext{
175 Author's fieldnotes.

176 Interview 2, 10 January 2018.

177 Interview 1, 8 January 2018.
} 


\section{VICTIMHOOD AND BENEFITTING FROM SITES OF ATROCITY}

The final area we wish to discuss in this chapter is how victims and survivors can and should benefit from the sites. A large number of our interviewees made the point that through visits to former atrocity sites, young people have the opportunity to learn about the past and work towards ensuring that it is not repeated in the future. These points were explored in more detail in Chapter 2. Our focus here is on how victims can benefit from (careful) interaction with the sites.

It is well established that for many victims and survivors of violent conflict and human rights abuses, the opportunity to engage with others who have similar experiences can help promote solidarity and a sense of community. ${ }^{178}$ These themes were echoed in Cambodia. Organisations involved in bringing survivors to the sites, whether as part of outreach programmes at the ECCC or as part of other community groups, and individuals who worked to provide psychological support all spoke to the therapeutic benefits of victims being able to meet each other and share their experiences - 'it's a space for survivors to tell their stories, but also a space where survivors can hear the stories of others who survived and other victims'. ${ }^{179}$ Such exchanges can promote social support and help to counter feelings of isolation that often accompany violent conflict. Of course, not all victims and survivors will find such processes helpful and indeed may find them retraumatising. For this reason, such interactions need to be managed with care and with appropriate support mechanisms in place.

Closely linked to the promotion of solidarity was the capacity of international tourists to acknowledge and 'validate' the experience of survivors and through their interest in the Cambodian genocide, redevelop trust in humanity: 'Their soul might rest in peace because more people [are] interest[ed] in their story and suffering'. ${ }^{180}$

...you know, the traumatised people or survivors of the Khmer Rouge regime has broken their trust, they don't trust the same people so to have international participation is only positive for them and they feel more acknowledgement to that. ${ }^{181}$

\footnotetext{
178 Druliolle, V. and Brett, R. (2018). The Politics of Victimhood in Post-conflict Societies: Comparative and Analytical Perspectives. Basingstoke: Palgrave Macmillan.

179 Interview 2, 5 January 2018.

180 Interview, 9 January 2018.

${ }^{181}$ Interview 2, 10 January 2018.
} 
A number of interviewees also raised the issue of survivors being in a position to financially benefit from the site. Given that entrance fees are required at Tuol Sleng and Choeung Ek, this concern was restricted to these two sites. The following exchange between a member of the research team and an interviewee well illustrates this point:

I: Do you think that at Tuol Sleng and Choeung Ek, the money should be going to victims?

P: Yes, because Tuol Sleng and Choeung Ek came from victim, that site came from the victim, if have no victim, have no Tuol Sleng and Choeung Ek. ${ }^{182}$

While wishing to retain ownership over their experiences, a number of survivors spoke of the importance of reparations being made to those who have suffered and as a result, have been unable to provide for themselves and their families:

A huge amount of income goes to the state. There should be some part of it going to the survivors to support their children to be educated or as a motivation for us to feel relief ... send our children to get more education until they finish the study. ${ }^{183}$

For at least one interviewee, this argument was reflective of broader questions on the willingness of the Cambodian government to recognize the needs of survivors, whether Tuol Sleng should be more directly victim facing and the privatization of Choeung Ek. Perhaps most challenging for the research team was the suggestion that the sites are seen as income generators first and places of suffering second by government and policy makers in Cambodia. ${ }^{184}$ One survivor went further to argue that given the relative lack of attention given to survivors by the government, 'selling' their story has become a way to generate income for their families, despite the obviously traumatic connotations of doing so. ${ }^{185}$

182 Interview 2, 5 January 2018.

183 Interview 2, 7 January 2018.

184 Interview 2, 6 January 2018.

185 Interview 2, 7 January 2018. 


\section{CONCLUSION}

This chapter explored the relationship between the sites and how the experience of victims and survivors of the Khmer Rouge has been represented. Our research pointed to four key points and builds upon the findings on truth, acknowledgment and education detailed in Chapter 2. First is the importance victims and survivors placed on being able to tell the story of their experiences. Second is the need to represent victims' voices as fully as possible, by, for example, giving victims and survivors the opportunity to 'bear witness' to the past and including their voices and insights in the development of the sites. Third is ensuring that the sites represent the diversity of experience and the range of harms that were perpetuated during the Khmer Rouge regime. This means expanding the focus from violent death and torture to include forced labour, starvation and sexual violence, amongst other harms. Finally, our interviewees pointed to the question of further thought being given to who benefits from the sites. In the following conclusion, we expand upon these points and their importance for sites of atrocity in Cambodia and other post-conflict and post-authoritarian societies.

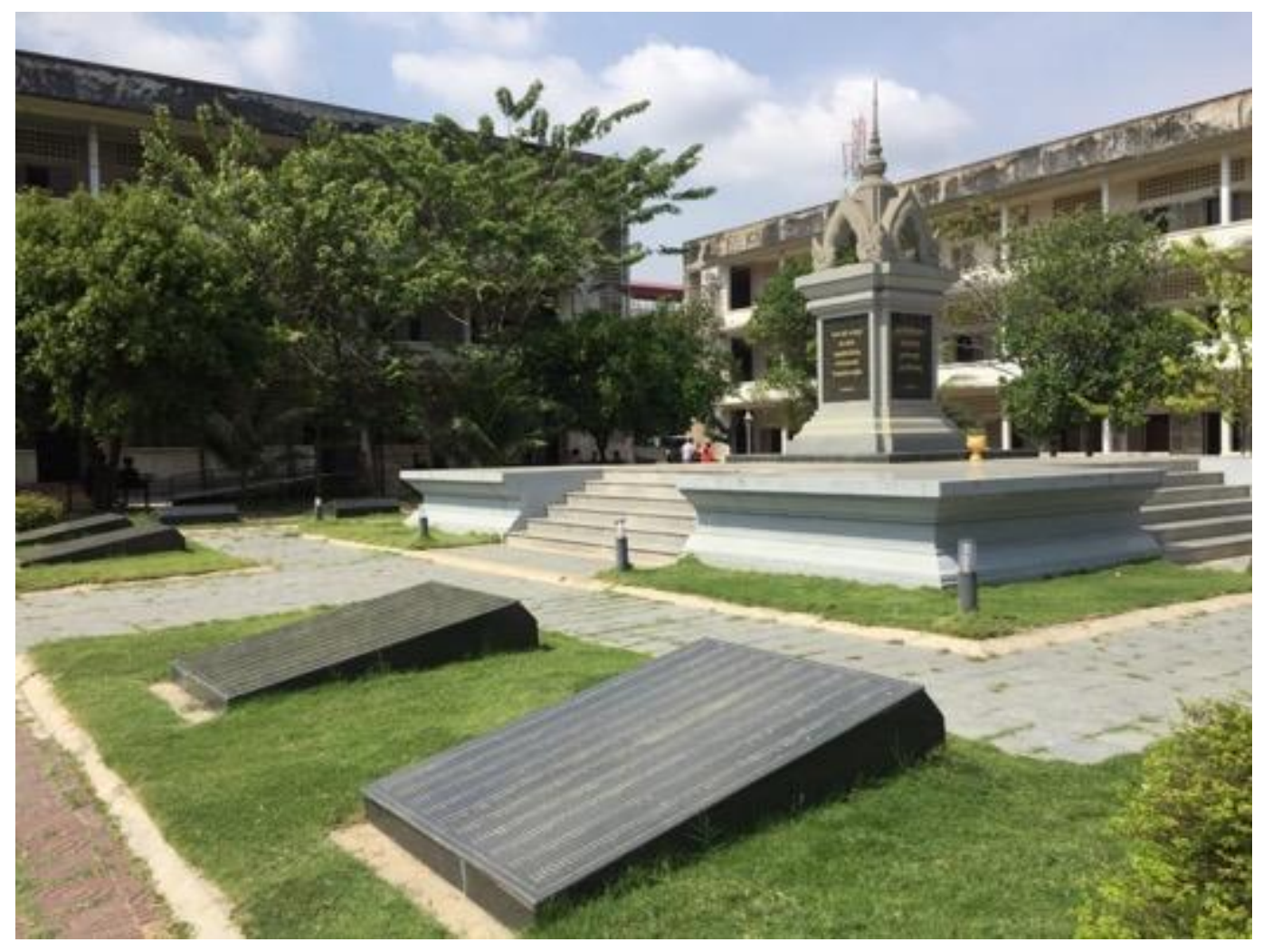

Figure 22: Stupa awarded as reparations by the Extraordinary Chambers in the Courts of Cambodia at Tuol Sleng Museum of Genocide 


\section{CHAPTER 4: CONCLUDING POINTS}

This research project sought to explore how victims' voices are represented in former sites of atrocity in Cambodia. Across the four sites of Tuol Sleng, Choeung Ek, Kraing Ta Chan and Kampong Chhang Airfield and through a range of interviews, we examined how those most directly affected by violence and human rights abuses have been able to contribute to the stories that are told in these sites. Some of the key themes emerging from this research include the relationship between former sites of atrocity and truth, healing and remembrance. Our findings also demonstrate the importance of bearing witness to the past and representing a range of victims' voices.

A considerable number of our interviewees stressed the importance of visiting former sites of atrocity. We agree with this. While we acknowledge that there is considerable diversity in the nature, context and physical manifestation of these sites, in the discussion below we make some tentative suggestions as to practices sites of dark tourism might adopt to ensure a sensitive and inclusive recognition of victimhood.

\section{Access}

It is important that survivors of past violence have the opportunity to visit sites connected to their experience. Where victims and survivors lack the resources to visit sites, efforts should be made to facilitate access. If possible, psychological and emotional support should be made available to survivors visiting the sites, as visiting such places brings risks of retraumatisation. Our interviewees often highlighted the importance of the younger generation visiting these sites, therefore developing schemes which further this goal may be appreciated and valued.

\section{Preservation and Authenticity}

It is often considered important that sites of past violence are preserved as a way of evidencing the past. Where possible, resources should be made available to preserve a range of sites, as a means of acknowledging harm across the country. When preserving sites of past atrocity and preparing them for the receiving of visitors, care should be taken that authenticity is maintained where possible. The addition of elements that are not considered to be a true reflection of what took place, the inclusion of reconstructions, or 
the addition of artefacts from other sites should be clearly indicated in the site signage, as failing to do so may attract criticism. One way to ensure authenticity is to ask those who were held at these sites, or who worked there, of their memories of how things were.

\section{Inclusion}

The best way to ensure that the needs of victims and survivors are met with regards these sites is to include them in discussions around their preservation, development, and design. This will ensure that those most impacted by past violence have the opportunity to express their agency and have their voice heard. The development of Kraing Ta Chan demonstrates that partnerships between NGOs and local communities can be one way of achieving greater representation of $\mathrm{KR}$ survivors at these sites. Providing opportunities for survivors to tell their stories can also be appreciated, and can facilitate dialogue between those impacted by the violence, and those who visit. Such opportunities could be offered to survivors who were harmed elsewhere, as a way of telling a fuller story about the past and including a wider range of experiences.

\section{Recognition and Representation}

The selection of sites for development, and the ways in which they are developed, shape how the past is understood and remembered. If their scope is too narrow, the experiences and harms suffered by some victims and survivors will be excluded. Survivors have repeatedly highlighted the value of having their harm recognised and represented in 'dark tourist' sites. We would suggest that the development of a range of sites of past atrocity, the inclusion of a diversity of victims' experiences, and engagement with the full range of harms suffered is the best way to ensure that the experiences of past violence are accurately represented.

\section{Education}

Our interviewees often highlighted the potential for sites of dark tourism to be used for educational purposes. There is a strong belief that understanding the past can prevent future violence from occurring. Developers and managers of dark tourist sites might wish to consider ways in which an educational role can be enhanced, for example by providing spaces for reflection, posing questions for visitors to consider and increasing opportunities for visitors to engage with survivors. If possible, a focus on genocide prevention could be incorporated, 
this might include lessons learned from the country's experiences, connections to international contexts, or suggesting ways to resist the early signs of violence.

\section{Respect and Sensitivity}

The visiting of sites of former violence by tourists can be valued by victims and survivors as a form of acknowledgment. However, it is important that visitors behave in a respectful way, and remember that they are in a place of memorialisation - and indeed, that relatives of those killed may also be at the sites. Visitor guidelines can be helpful in ensuring this, as can providing areas for peaceful reflection. Developers and managers should also be mindful that over-commercialisation, for example through the inclusion of souvenir shops, might be deemed disrespectful by survivors. Organising the space appropriately, for instance by placing such businesses outside the parameters of the site, can provide a means of mitigating this tension. The overarching principles of respect and sensitivity should be observed. 


\section{BIBLIOGRAPHY}

Aldana, R. (2006). 'A Victim-Centered Reflection on Truth Commissions and Prosecutions as a Response to Mass Atrocities', Journal of Human Rights, 5, 1: $107-126$.

Bennett, C. (2015). To Live Amongst the Dead: An Ethnographic Exploration of Mass Graves in Cambodia. University of Kent: Unpublished PhD thesis. Copy on file with authors.

Bouris, E. (2007). Complex Political Victims. Connecticut: Kumarian.

Cohen, S. (1995). 'State Crimes of Previous Regimes: Knowledge, Accountability, and the Policing of the Past', Law \& Social Inquiry, 20, 1: 750 .

Davis, E. (2016). Deathpower: Buddhism's Ritual Imagination in Cambodia. New York: Columbia University Press.

Druliolle, V. and Brett, R. (2018). The Politics of Victimhood in Post-conflict Societies: Comparative and Analytical Perspectives. Basingstoke: Palgrave Macmillan.

Firchow, P. (2014). 'The Implementation of the Institutional Programme of Collective Reparations in Colombia,' Journal of Human Rights Practice, 6, 2: 356-375.

Fletcher, L. and Weinstein, H. (2017). 'Transitional justice and the 'plight' of victimhood'. In: Lawther, C., Moffett, L. and Jacobs, D. (eds). Research Handbook on Transitional Justice. Cheltenham: Edward Elgar. pp.244-266.

Govier, T. (2015). Victims and Victimhood. Peterborough, Canada: Broadview Press.

Hamber, B. and Wilson, R.A. (2002). 'Symbolic Closure Through Memory Reparation and Revenge in Post-Conflict Societies', Journal of Human Rights, $1,1: 35-53$.

Hayner, P. B. (2011). Unspeakable Truths: Transitional Justice and the Challenge of Truth Commissions. 2nd Edition. New York; Oxon: Routledge. 
Henkin, S. (2018). 'Postmemory and the Geographies of Violence at Kraing Ta Chan, Cambodia', GeoHumanities, 4, 2: 462-480.

Khet, L. (2011). Initiating a Way to Address Legacy of Memory in Cambodia. Youth for Peace; The Peace Institute of Cambodia: Action Research Paper.

Kiernan, B. (2008). The Pol Pot Regime: Race, Power and Genocide in Cambodia under the Khmer Rouge, 1975-79. $3^{\text {rd }}$ ed. New York: Yale University Press.

Laub, D. (1992). 'Bearing Witness, or the Vicissitudes of Listening'. In: Feldman, S. and Laub, D. (eds). Testimony: Crises of Witnessing in Literature, Psychoanalysis, and History. Abingdon: Taylor and Francis. pp.57-74

Lawther, C. (2014). 'The Construction and Politicisation of Victimhood'. In: Lynch, O. and Argomaniz, J. (eds). Victims of Terrorism: A Comparative and Interdisciplinary Study. London: Routledge. pp.10-30

Lawther, C. (2014). Truth, Denial and Transition. Northern Ireland and the Contested Past. Abingdon: Routledge

Lederach, J.P. (1997). Building Peace: Sustainable Reconciliation in Divided Societies. Washington: United States Institute of Peace Press.

Lessa, F. (2011), 'Beyond Transitional Justice: Exploring Continuities in Human Rights Abuses in Argentina between 1976 and 2010,' Journal of Human Rights Practice, 3, 1: 25-48.

'List of Democratic Kampuchea Prison', Documentation Centre of Cambodia, 5 January 2005, available at www.d.dccam.org/Projects/Maps/Mass Graves Study.htm (accessed 20/02/19)

Mawby, R. and Walklate, S. (1994). Critical Victimology: International Perspectives. London: SAGE.

McEvoy, K. and McConnachie, K. (2013). 'Victims and transitional justice: voice, agency and blame', Social and Legal Studies, 22, 4: 489-513.

McEvoy, K. and McGregor, L. (2008). Transitional Justice from Below. Grassroots Activism and the Struggle for Change. London: Hart. 
Mendeloff, D. (2009). 'Trauma and Vengeance: Assessing the Psychological and Emotional Effects of Post-Conflict Justice', Human Rights Quarterly, 33, 3: 592-623.

Roht-Arriaza, N. (2004). 'Reparations Decisions and Dilemmas,' Hastings International and Comparative Law Review, 27, 2: 157-219.

Roht-Arriaza, N. (2006). 'The New Landscape of Transitional Justice.' In: RohtArriaza, N. and Mariezcurrena, J. (eds.) Transitional Justice in the $21^{\text {st }}$ Century. Cambridge: Cambridge University Press. pp.1-16.

TPO Cambodia, 'What We Do,' available at: https://tpocambodia.org/healingand-reconciliation-for-victims-of-torture-of-khmer-rouge-trauma/ (accessed 07/03/2019)

TPO (2017) Annual Report 2017, available at: http://tpocambodia.org/wpcontent/uploads/2014/07/Final-Annual-report-2017.pdf (accessed 07/03/18)

Tyner, J. (2016). Landscape, Memory and Post-Violence in Cambodia. London: Rowan and Littlefield.

UNESCO, 'Speech: Launch of Digitization of Toul Sleng Museum's Document, open remarks by Ms. Anne Lemaistre, UNESCO Representative in Cambodia' http://www.unesco.org/new/en/phnompenh/about-this-office/singleview/news/speech launch of digitization of toul sleng museums docu/ (accessed 09/01/18)

Verdery, K. (1999). The Political Lives of Dead Bodies. New York: Colombia University Press.

Youth for Peace. (2011). 10 Years of Peace Activism. Youth for Peace; The Peace Institute of Cambodia: Action Research Paper.

\section{Case List}

Case 001, Trial Judgement, 001/18-07-2007/ECCC/TC, 26 July 2010

Case 001, Appeal Judgement, 001/18-07-2007/ECCC/SC, 3 February 2012

Case 002/02 Judgement Summary, 002/19-09-2007/ECCC/TC, 16 November 2018 
Case 002/02, Trial Judgement, 002/19-09-2007/ECCC/TC, 16 November 2018 